\title{
17. TIME-PROGRESSIVE MORPHOMETRIC CHANGES OF THE GENUS GEPHYROCAPSA IN THE QUATERNARY SEQUENCE OF THE TROPICAL INDIAN OCEAN, SITE 7091
}

\author{
Hiromi Matsuoka ${ }^{2}$ and Hisatake Okada ${ }^{3}$
}

\begin{abstract}
Stratigraphic variations in the morphometry of the genus Gephyrocapsa (calcareous nannoplankton) were quantitatively investigated in the Quaternary sequence of Hole 709C recovered from the tropical Indian Ocean. Gephyrocapsa can be roughly divided into groups of small and large Gephyrocapsa, mainly on the basis of their significant differences in coccolith size. Four lineages were recognized among the large Gephyrocapsa, and members of these lineages were tentatively named Gephyrocapsa sp. A, B, C, and D. These species are approximately $3 \mu \mathrm{m}$ large at their incipient stages, and the latter three species become progressively larger thereafter. In the case of Gephyrocapsa sp. B and C, well-developed large forms disappeared abruptly, only to be succeeded by a new cycle of evolutionary size increase, respectively performed by Gephyrocapsa sp. C and D.

The first cycle observed in Gephyrocapsa sp. B occurred at the 16.02-12.02 mbsf interval (around 1.6-1.1 Ma), and Gephyrocapsa sp. A occurred simultaneously within this cycle. The second and third cycles, performed respectively by Gephyrocapsa sp. C and D, occurred at $9.62-6.02 \mathrm{mbsf}$ (around 0.9-0.5 Ma) and above $5.62 \mathrm{mbsf}(0.5 \mathrm{Ma}$ to the present). The percentage abundance of large Gephyrocapsa species that showed an evolutional size increase conversely decreased with an increase in overall size. An interval lacking the large species that roughly corresponds to the "small Gephyrocapsa zone" was found between the first and second cycles, but changes in abundance of the small and large forms seem to be independent.

The appearance and disappearance of the large forms as well as their changes in overall size and abundance play major roles in the floral change throughout the Quaternary. The six nannoflora assemblages dividing the last 1.3 m.y. reported from the subtropical Pacific Ocean were also recognized in the tropical Indian Ocean. A new additional assemblage was identified in the basal part of the Pleistocene.
\end{abstract}

\section{INTRODUCTION}

Matsuoka and Okada (1989) studied time-progressive changes in the floral compositions and morphometries of major calcareous nannofossil taxa during the last $1.3 \mathrm{~m} . \mathrm{y}$. in the subtropical northwestern Pacific Ocean. They semiquantitatively measured the morphology of several placolith groups and demonstrated the existence of remarkable time-progressive changes in morphology as well as in the overall size of the Gephyrocapsa species. Because these measurements were conducted in a semiquantitative mode, details of the morphologic changes that have strong potential for paleoceanography as well as for improved Quaternary biostratigraphy are yet to be clarified.

A complete sequence of Quaternary sediment was retrieved from the tropical Indian Ocean at Hole 709C, and a set of highresolution samples taken at $10-\mathrm{cm}$ intervals was available to us for a quantitative study of Quaternary nannofossils. The purposes of this study were to investigate quantitatively the timeprogressive changes in the morphometry of the genus Gephyrocapsa throughout the entire Quaternary period in the tropical Indian Ocean and to provide a base for the phylogeny of the genus and for the paleoceanography of this region. The results observed will also be examined for applicability to the improved biostratigraphy.

\section{MATERIALS AND METHODS}

Hole $709 \mathrm{C}$ is located in the western tropical Indian Ocean at $3^{\circ} 54.9^{\prime} \mathrm{S}$ and $60^{\circ} 33.1^{\prime} \mathrm{E}$ in a water depth of $3038.2 \mathrm{~m}$. We iden-

\footnotetext{
${ }^{1}$ Duncan, R. A., Backman, J., Peterson, L. C., et al., 1990. Proc. ODP, Sci. Results, 115: College Station, TX (Ocean Drilling Program).

2 Graduate School of Natural Science and Technology, Kanazawa University, Kanazawa 920, Japan.

${ }^{3}$ Department of Earth Sciences, Faculty of Science, Yamagata University, Yamagata 990 , Japan.
}

tified the occurrence of the eight datum events, excluding the first occurrence (FO) of Emiliania huxleyi, under a light microscope in a full set of 10-cm-interval samples. The FO of E. huxleyi was determined under an electron microscope. The sedimentation rate obtained by plotting these datum events proved to be rather constant throughout the Quaternary at the average rate of $0.94 \mathrm{~cm} /$ k.y. (Fig. 1). We selected a set of 45 samples representative of the entire Quaternary sequence from Cores $115-709 \mathrm{C}-1 \mathrm{H}$ through $-3 \mathrm{H}$ at $40-\mathrm{cm}$ intervals to study the morphometry of the Gephyrocapsa complex (Table 1).

These samples were made into carbon replicas for detailed observation under a transmission electron microscope (TEM). The first 200 specimens of Gephyrocapsa species were measured for the overall size of the coccolith, the diameter of the central opening, and the angle of the central bridge vs. the long axis of the coccolith. The two lengths were measured to $0.1-\mu \mathrm{m}$ precision. Because the bridge angle is difficult to measure precisely under a transmission microscope, it was classified into six categories: $0^{\circ}, 15^{\circ}, 15^{\circ}-30^{\circ}, 30^{\circ}-45^{\circ}, 45^{\circ}-60^{\circ}, 60^{\circ}-75^{\circ}$, and $75^{\circ}$ $90^{\circ}$. For those samples in which the small forms dominated the flora and the large forms were scarce, additional measurements were conducted exclusively for the large forms to obtain a sufficient data set. We also measured the composition of the flora, excluding the ubiquitous Florisphaera profunda, by identifying the first 200 coccoliths encountered. Advanced dissolution affects the preservation of nannofossils, and many fragmented specimens were observed in some samples. We identified and measured only reasonably well-preserved specimens.

\section{CLASSIFICATION OF GEPHYROCAPSA TAXA}

There are many extant or extinct species classified under the genus Gephyrocapsa, and the majority of these species are defined solely by morphologic characters to aid Quaternary biostratigraphy. The purpose of this investigation, on the other hand, is to study the time-progressive changes in morphometry 


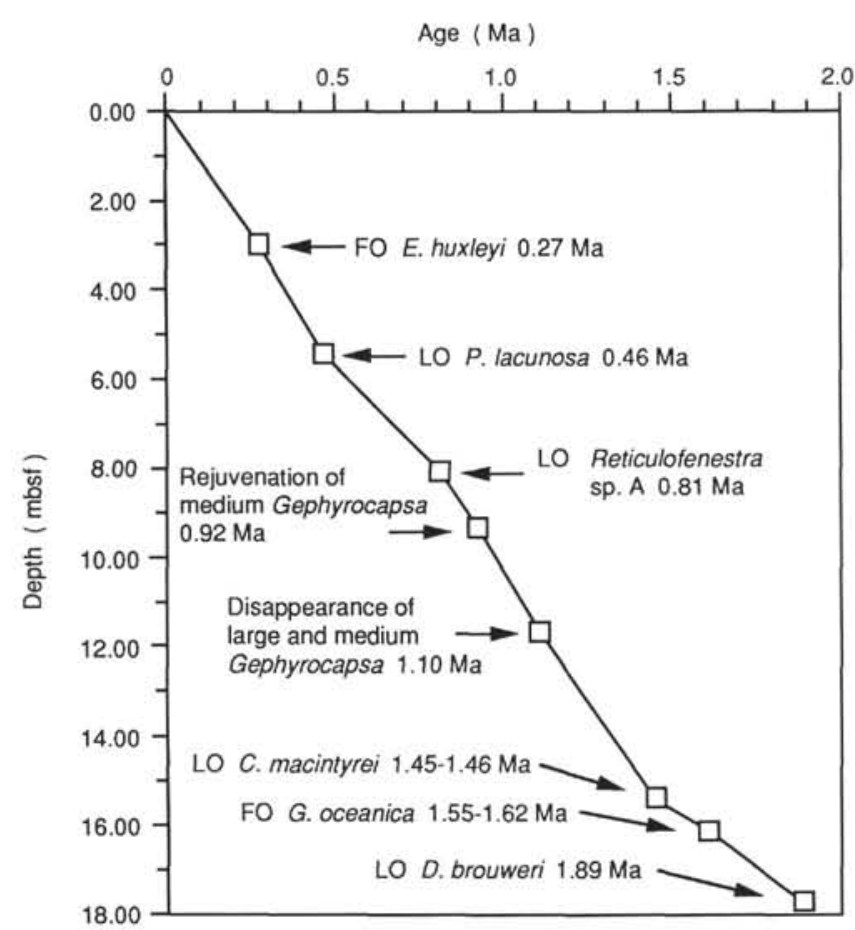

Figure 1. Depth-age relationship for the Quaternary sequence of Hole 709C. Biostratigraphic datum events are adopted from Matsuoka and Okada (1989) for the upper five events and from Rio et al. (in press) for the lower three events. The occurrences of datum events were determined by light microscopy except for the first occurrence of Emiliania huxleyi, which was determined under an electron microscope.

as well as in floral compositions of the Gephyrocapsa complex. During the course of our investigations, we have realized that various groups of the Gephyrocapsa complex underwent considerable size and morphologic changes in a successive manner. These groups, which were identified by forming clusters in a plot of overall size vs. proportion of central opening (Fig. 2), are actually evolutional lineages. Because the end members that occurred within each lineage are considerably different in size and morphology, biostratigraphers may have classified them into separate species.

Actually, most of the specimens observed in this investigation can be assigned to existing Gephyrocapsa species, and more than one existing species is recognized within each lineage. The classification of the genus Gephyrocapsa itself is, however, presently in disagreement among specialists, and some specimens that occur between different lineages are difficult to separate from each other. Because we consider these lineages to be independent species, and because it is almost impossible to apply the existing taxonomy to describe our species, we were forced to employ a completely different classification to describe our results. Thus, our principle scheme of classification is completely different from the usual taxonomic scheme used for biostratigraphy. We decided to name our species with alphabetic characters to avoid further confusion in this troublesome, yet biostratigraphically useful group of nannofossils.

Actually, we identified two groups, the small and large $\mathrm{Ge}$ phyrocapsa, within the Gephyrocapsa complex. These two groups were easily separated in the plots of the overall size of coccolith vs. the diameter of the central opening in most of the samples, but they were mixed together and were inseparable within some intervals (Fig. 2). The boundary drawn between these groups is interdependent on the coccolith size and the size of the central
Table 1. List of studied samples.

\begin{tabular}{|c|c|}
\hline $\begin{array}{l}\text { Core, section, } \\
\text { interval }(\mathrm{cm})\end{array}$ & $\begin{array}{l}\text { Depth } \\
\text { (mbsf) }\end{array}$ \\
\hline \multicolumn{2}{|l|}{$115 \mathrm{~B}-709 \mathrm{C}-$} \\
\hline $1 \mathrm{H}-1,2-3$ & 0.02 \\
\hline $1 \mathrm{H}-1,42-43$ & 0.42 \\
\hline $1 \mathrm{H}-1,82-83$ & 0.82 \\
\hline $1 \mathrm{H}-1,122-123$ & 1.22 \\
\hline $1 \mathrm{H}-2,12-13$ & 1.62 \\
\hline $1 \mathrm{H}-2,52-53$ & 2.02 \\
\hline $1 \mathrm{H}-2,92-93$ & 2.42 \\
\hline $1 \mathrm{H}-2,132-133$ & 2.82 \\
\hline $1 \mathrm{H}-3,22-23$ & 3.22 \\
\hline $1 \mathrm{H}-3,62-63$ & 3.62 \\
\hline $1 \mathrm{H}-3,102-103$ & 4.02 \\
\hline $1 \mathrm{H}-3,142-143$ & 4.42 \\
\hline $1 \mathrm{H}-4,32-33$ & 4.82 \\
\hline $1 \mathrm{H}-4,72-73$ & 5.22 \\
\hline $1 \mathrm{H}-4,112-113$ & 5.62 \\
\hline $2 \mathrm{H}-1,22-23$ & 6.02 \\
\hline $2 \mathrm{H}-1,62-63$ & 6.42 \\
\hline $2 \mathrm{H}-1,102-103$ & 6.82 \\
\hline $2 \mathrm{H}-1,142-143$ & 7.22 \\
\hline $2 \mathrm{H}-2,32-33$ & 7.62 \\
\hline $2 \mathrm{H}-2,72-73$ & 8.02 \\
\hline $2 \mathrm{H}-2,112-113$ & 8.42 \\
\hline $2 \mathrm{H}-3,2-3$ & 89 \\
\hline $2 \mathrm{H}-3,42-43$ & 9.22 \\
\hline $2 \mathrm{H}-3,82-83$ & 9 \\
\hline $2 \mathrm{H}-3,122-123$ & 10.02 \\
\hline $2 \mathrm{H}-4,12-13$ & 10.42 \\
\hline $2 \mathrm{H}-4,52-53$ & 10.82 \\
\hline $2 \mathrm{H}-4,92-93$ & 11.22 \\
\hline $2 \mathrm{H}-4,132-133$ & 11.62 \\
\hline $2 \mathrm{H}-5,22-23$ & 12.02 \\
\hline $2 \mathrm{H}-5,62-63$ & 12.42 \\
\hline $2 \mathrm{H}-5,102-103$ & 12.8 \\
\hline $2 \mathrm{H}-5,142-143$ & 13.22 \\
\hline $2 \mathrm{H}-6,32-33$ & 13.6 \\
\hline $2 \mathrm{H}-6,72-73$ & 14.0 \\
\hline $2 \mathrm{H}-6,112-113$ & 14.4 \\
\hline $2 \mathrm{H}-7,2-3$ & 14.8 \\
\hline $2 \mathrm{H}-\mathrm{CC}, 2-3$ & 15. \\
\hline $3 \mathrm{H}-1,22-23$ & 15.6 \\
\hline $3 \mathrm{H}-1,62-63$ & 16. \\
\hline $3 \mathrm{H}-1,102-103$ & 16. \\
\hline $3 \mathrm{H}-1,142-143$ & 16.8 \\
\hline $3 \mathrm{H}-2,32-33$ & 17.2 \\
\hline $3 \mathrm{H}-2,72-73$ & 17.6 \\
\hline
\end{tabular}

opening, and it ranges between 2.0 and $3.5 \mu \mathrm{m}$ for the overall coccolith size (Fig. 2). Because the boundary is diagonal to the horizontal axis of Figure 2, which represents the overall coccolith size, the simple separation of these two groups by a predetermined overall size is impossible.

In practice, specimens $<2.0 \mu \mathrm{m}$ and $>3.5 \mu \mathrm{m}$ are automatically classified as small Gephyrocapsa and large Gephyrocapsa, respectively. Specimens with overall sizes that range between these boundary sizes are divided according to their position in the coccolith-size/central-opening-size plot as well as by their general appearance.

The small Gephyrocapsa group includes small forms with large central openings, and it may consist of several species, such as Gephyrocapsa aperta, Gephyrocapsa ericsonii, Gephyrocapsa pelta, Gephyrocapsa protohuxleyi, and Gephyrocapsa sinuosa. Because it is easy to identify and has biostratigraphic potential, G. protohuxleyi is the only species identified as a separate entity, and all other small Gephyrocapsa are lumped under the name of Gephyrocapsa spp. (small). As we will mention 

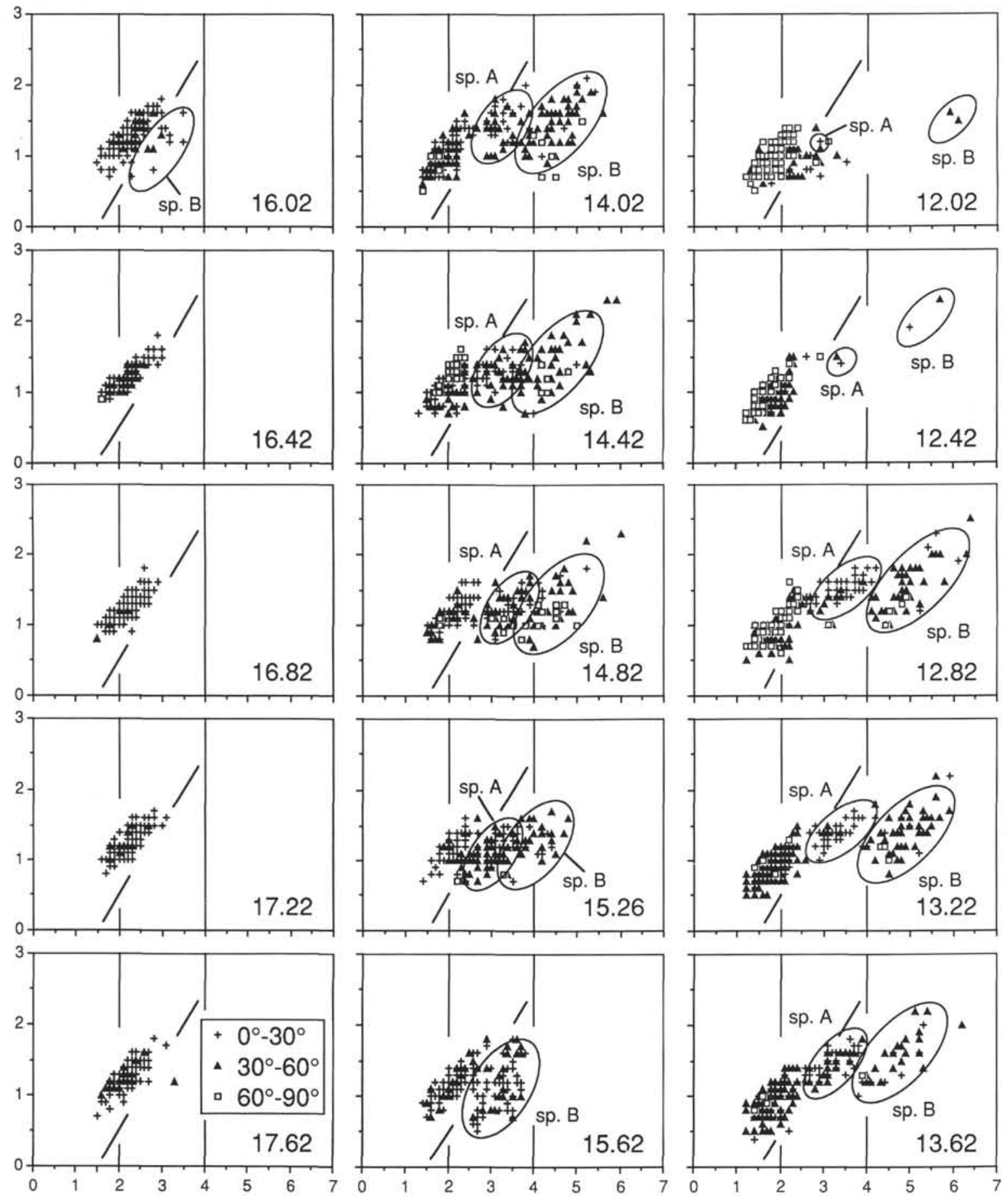

Figure 2. Plot of overall coccolith size (horizontal axis) vs. diameter of central opening (vertical axis) for the 200 specimens of $G e$ phyrocapsa observed in the samples studied. Numerical values in the lower right-hand corner of each plot indicate sub-bottom depth (expressed in mbsf) of each sample. The horizontal and vertical scales are expressed in $\mu \mathrm{m}$. The diagonal line indicates the boundary between small and large Gephyrocapsa. In the six samples between 14.82 and $12.82 \mathrm{mbsf}$, in which large Gephyrocapsa are rather scarce, additional plots of approximately 100 specimens were added to clarify the trend of the morphometric changes. The six categories of the bridge angle ( $15^{\circ}$ interval), which denotes the inclination of the bridge vs. the long axis of the coccolith, were regrouped into three categories $\left(30^{\circ}\right.$ interval) to make each plot identifiable in this figure. Crosses $=$ specimens with low bridge angles $\left(0^{\circ}-30^{\circ}\right)$; solid triangles $=$ specimens with medium $\left(30^{\circ}-60^{\circ}\right)$ bridge angles; open squares $=$ specimens with high $\left(60^{\circ}-90^{\circ}\right)$ bridge angles. 

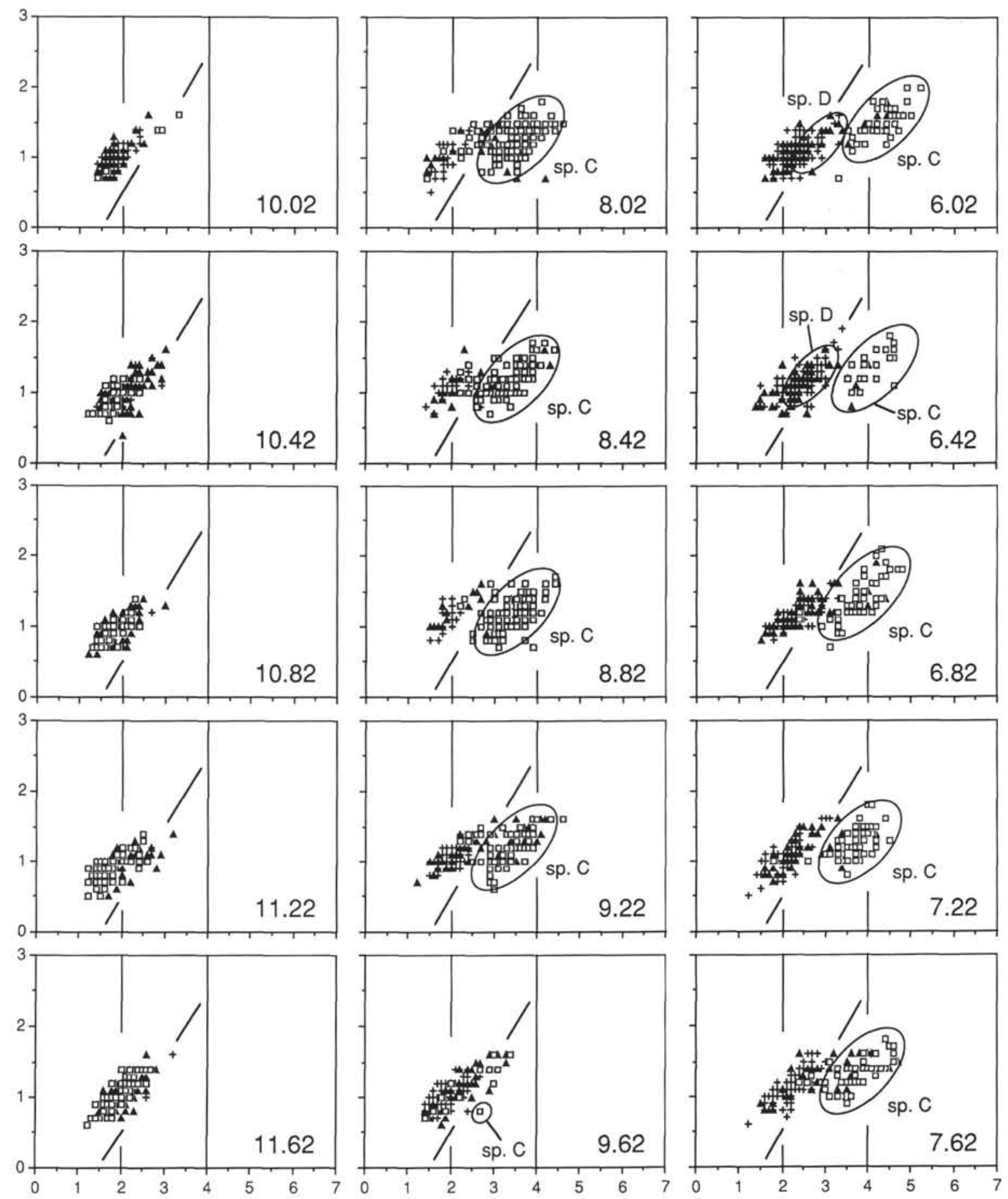

Figure 2 (continued).

later, a possible ancestral taxon of $G$. protohuxleyi was also identified, and hence, three taxa were identified within the small Gephyrocapsa.

In addition to the separation into small and large forms, Figure 2 shows that there are four clusters of large Gephyrocapsa. Although one lower cluster does not change its size throughout its existence, the three other clusters become time-transgressively larger and result in three evolutional cycles. Indeed, each of these cycles is mainly determined by the size increase of each corresponding type of large Gephyrocapsa, and the stratigraphic ranges of these cycles do not overlap for the most part (Fig. 2) These clusters are interpreted as lineage, and members of each cluster are tentatively identified as Gephyrocapsa sp. A, B, C, and D: Gephyrocapsa sp. A for the cluster with no size increase; and Gephyrocapsa sp. B, C, and D for the members of the lower (first evolutional cycle), middle (second cycle), and upper (third cycle) clusters, respectively. Although there are other large Gephyrocapsa that are not members of these four lineages, these large Gephyrocapsa, identified as Gephyrocapsa spp. (large), are not important elements of the Gephyrocapsa complex be- 

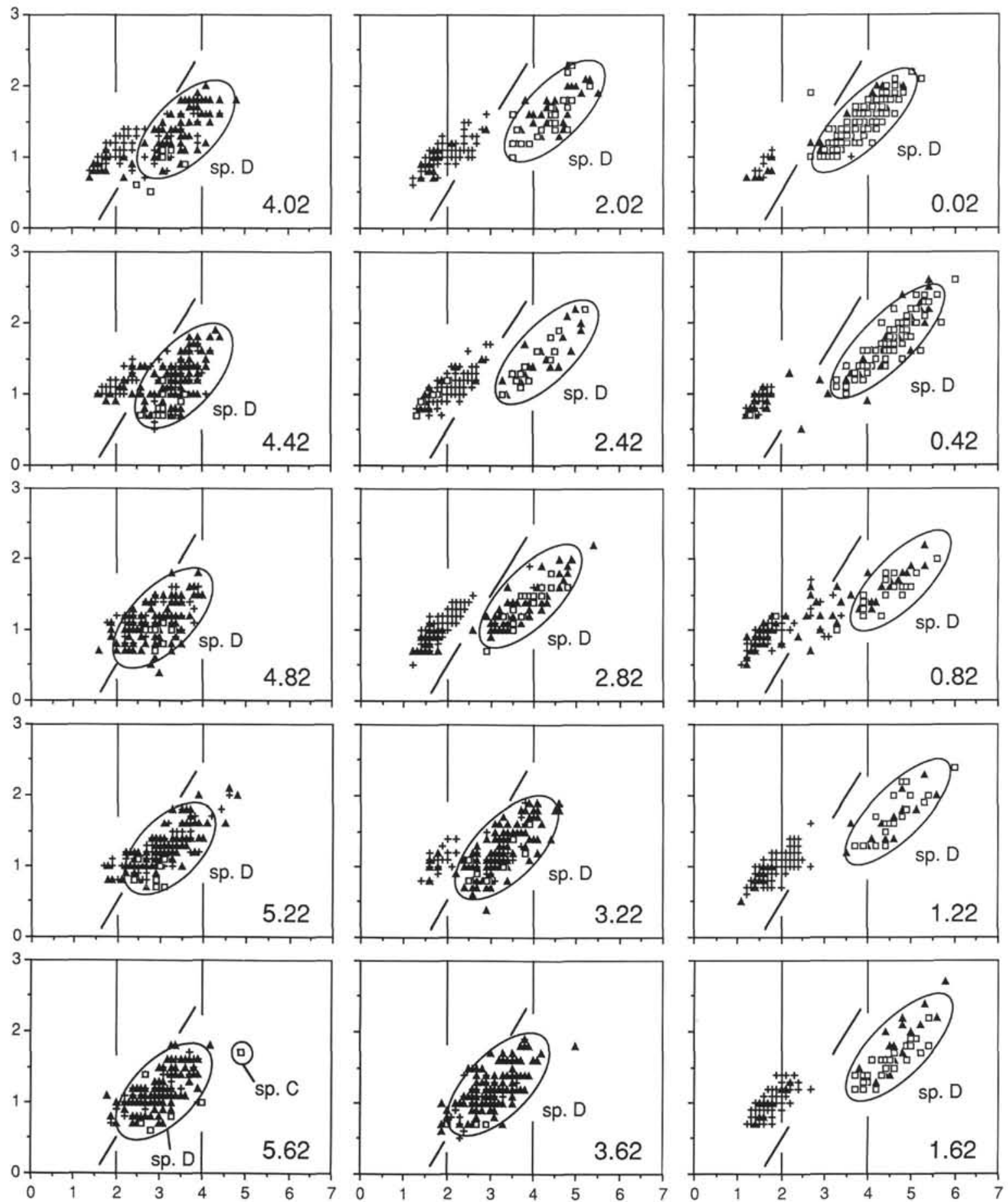

Figure 2 (continued).

cause of their rare occurrences. The classification and taxonomy we have employed are summarized in Table 2.

\section{TIME-PROGRESSIVE CHANGE IN MORPHOMETRY OF GEPHYROCAPSA}

\section{Small Gephyrocapsa Group}

The lowest interval of the sequence studied (between 17.62 and $16.42 \mathrm{mbsf}$ ) corresponds to the top of the Pliocene and the base of the Pleistocene. Although Gephyrocapsa spp. (small) dominate the assemblage of the Gephyrocapsa complex, the mor- phologic diversity is low. Specimens that occur in this interval possess a low-angled $\left(<30^{\circ}\right)$ bridge and are fairly large in overall size for the small Gephyrocapsa (Fig. 3).

Overall size and bridge angle of Gephyrocapsa spp. (small) change markedly within the lower Quaternary sequence, which corresponds to the interval between 16.02 and 10.02 mbsf. At $1602 \mathrm{mbsf}$, most specimens have a low-angled $\left(>30^{\circ}\right)$ bridge and an average overall size of $2.2 \mu \mathrm{m}$ (Fig. 3). Specimens with moderate bridge angles $\left(30^{\circ}-60^{\circ}\right)$ occur abundantly at 13.62 mbsf, and the average coccolith size is reduced to $1.8 \mu \mathrm{m}$. At 12.02 mbsf, the majority of small Gephyrocapsa show high 
Table 2. Classification of Gephyrocapsa complex employed in this study.

Small forms of Gephyrocapsa

$\begin{array}{lr}\text { G. protohuxleyi } & \text { G. protohuxleyi (s. str.) } \\ \text { Gephyrocapsa spp. (small) } & \text { G. protohuxleyi var. A }\end{array}$

Large forms of Gephyrocapsa

Gephyrocapsa sp. A

Gephyrocapsa sp. B

Gephyrocapsa sp. C

Gephyrocapsa sp. D

Gephyrocapsa spp. (large)

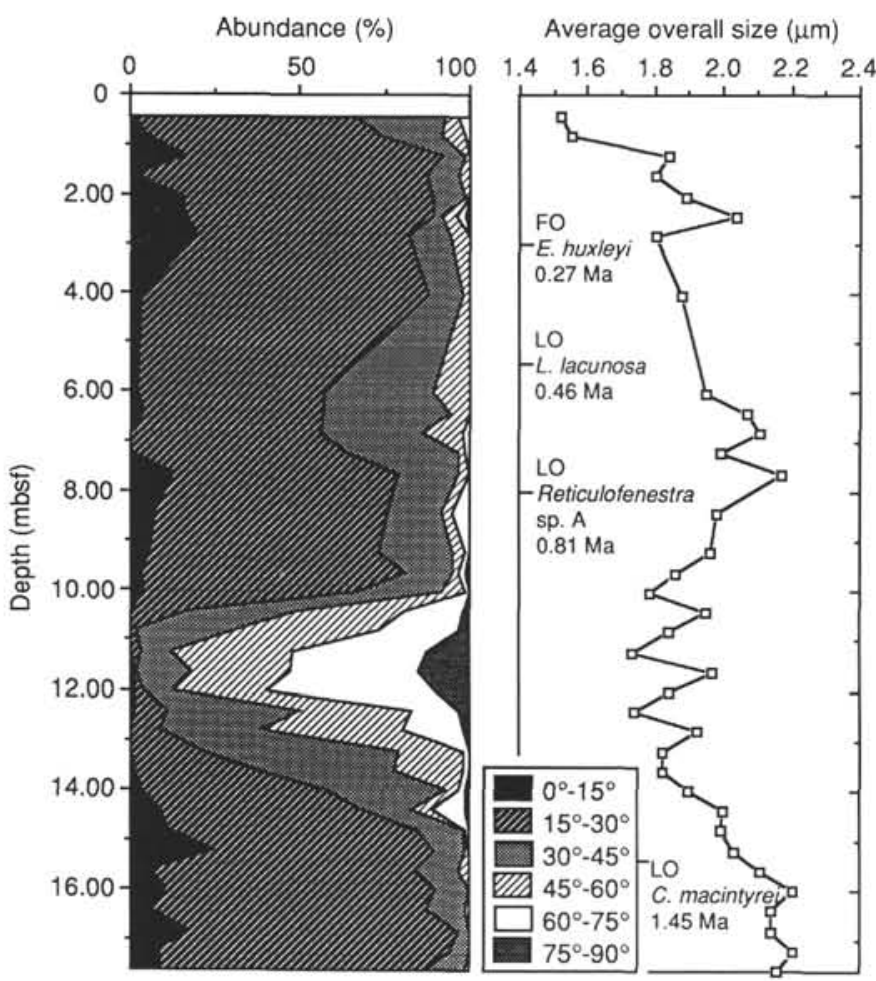

Figure 3. Stratigraphic changes in the percentage abundance of the six categories of Gephyrocapsa spp. (small) divided by bridge angles (left column) and in average coccolith size of the Gephyrocapsa spp. (small) (right column). Gephyrocapsa protohuxleyi is excluded from the plot, and samples in which Gephyrocapsa spp. (small) do not occur in large numbers are also omitted.

$\left(>60^{\circ}\right)$ bridge angles. In the two top samples of the lower sequence (10.42 and 10.02 mbsf), specimens with high bridge angles disappeared rather abruptly, and specimens with low $\left(<30^{\circ}\right)$ bridge angles again showed up abundantly.

A small Gephyrocapsa that Matsuoka and Okada (1989) identified as Gephyrocapsa protohuxleyi var. A occurs between 11.62 and 6.02 mbsf, and typical Gephyrocapsa protohuxleyi occurs in small amounts between 2.42 and 0.82 mbsf. These two taxa are not differentiated in Figure 2, and their occurrence is discussed below.

Gephyrocapsa spp. (small) is less abundant between 9.22 and $3.22 \mathrm{mbsf}$, and specimens with low bridge angles are common in this interval (Figs. 2 and 3). Small Gephyrocapsa with rather large coccolith sizes and low $\left(<30^{\circ}\right)$ bridge angles are abundant in the upper interval between 2.82 and $1.22 \mathrm{mbsf}$ (Fig. 3). In the topmost sequence (0.82-0.02 mbsf), Gephyrocapsa spp. (small) are extremely small $(1.0-2.0 \mu \mathrm{m})$ and decline noticeably in the total nannoflora (Figs. 2 and 3 ).

\section{Large Gephyrocapsa Group}

As previously mentioned, four species of large Gephyrocapsa and three evolutional cycles were recognized through the entire Quaternary.

\section{The First Cycle}

Gephyrocapsa sp. A, which has a robust low-angled $\left(<30^{\circ}\right)$ bridge and a large central opening, and Gephyrocapsa sp. B, characterized by a slim bridge span at moderate angles $\left(30^{\circ}-\right.$ $60^{\circ}$ ), a fairly small central opening, and an obscure central collar, are components of the first cycle, which was recognized between 16.02 and 12.02 mbsf (Figs. 2 and 4). Gephyrocapsa sp. A does not change in coccolith size significantly, and it is generally smaller as well as morphologically more diverse than $\mathrm{Ge}$ phyrocapsa sp. B.

The FO of large Gephyrocapsa, the cluster of early Gephyrocapsa sp. A and B, was recognized at $16.02 \mathrm{mbsf}$; its average coccolith size is approximately $3 \mu \mathrm{m}$ (Fig. 4). The large Gephyrocapsa started to diverge into Gephyrocapsa sp. A and B at 15.26 mbsf, but it is difficult to draw an exact boundary between these two taxa at this level (Fig. 2). The clusters of these two taxa were distinguishable above $13.62 \mathrm{mbsf}$, and both taxa simultaneously disappeared at 12.02 mbsf. Because the average overall size of Gephyrocapsa sp. B increases to $>5 \mu \mathrm{m}$, this species is conspicuous under a light microscope. Specimens that are about $3 \mu \mathrm{m}$ in overall size and have a small central opening appeared abruptly at 12.02 mbsf (Fig. 2). These specimens are classified as Gephyrocapsa spp. (large).

Large Gephyrocapsa scarcely occur in the interval between 11.62 and 10.02 mbsf. The very rare large Gephyrocapsa observed here are fairly small and are also classified as Gephyrocapsa spp. (large).

\section{The Second Cycle}

Gephyrocapsa sp. C is the main constituent of the second cycle, which was identified between 9.62 and 6.02 mbsf (Fig. 4). A high bridge angle $\left(>60^{\circ}\right)$ characterizes this species (Fig. 5). It first appeared at $9.62 \mathrm{mbsf}$ and became abundant in the interval between 9.22 and 8.02 mbsf. It was conversely reduced in abundance as the overall size increased (Fig. 4). The average coccolith size in this cycle is $3.2 \mu \mathrm{m}$ at $9.22 \mathrm{mbsf}$, which increased to $4.2 \mu \mathrm{m}$ at $6.02 \mathrm{mbsf}$. The last occurrence (LO) of Gephyrocapsa $\mathrm{sp}$. C is marked by a single specimen that occurred at $5.62 \mathrm{mbsf}$.

A group of specimens clustering along the boundary between large and small Gephyrocapsa at 6.42 and 6.02 mbsf was easily distinguishable from Gephyrocapsa sp. C (Fig. 2). This group exhibited transitional features between Gephyrocapsa sp. C and Gephyrocapsa spp. (small) and was tentatively included into $\mathrm{Ge}$ phyrocapsa sp. C.

\section{The Third Cycle}

Gephyrocapsa sp. D undergoes significant bridge angle changes throughout its stratigraphic range. It forms a main cluster in the third cycle in the upper Quaternary sequence above 5.62 mbsf.

The acme of Gephyrocapsa sp. D occurs between 5.62 and 3.22 mbsf (Fig. 4). The specimens observed in this interval are fairly small, the bridge angle is low $\left(<45^{\circ}\right)$, and the proportion of the central opening vs. the coccolith length varies greatly $(25 \%-55 \%)$ (Fig. 5). This species became larger in the higher interval between 2.82 and $1.22 \mathrm{mbsf}$, and specimens with higher $\left(>45^{\circ}\right)$ bridge angles as well as a narrow range in the proportion of the central opening $(30 \%-45 \%)$ are more common (Fig. 


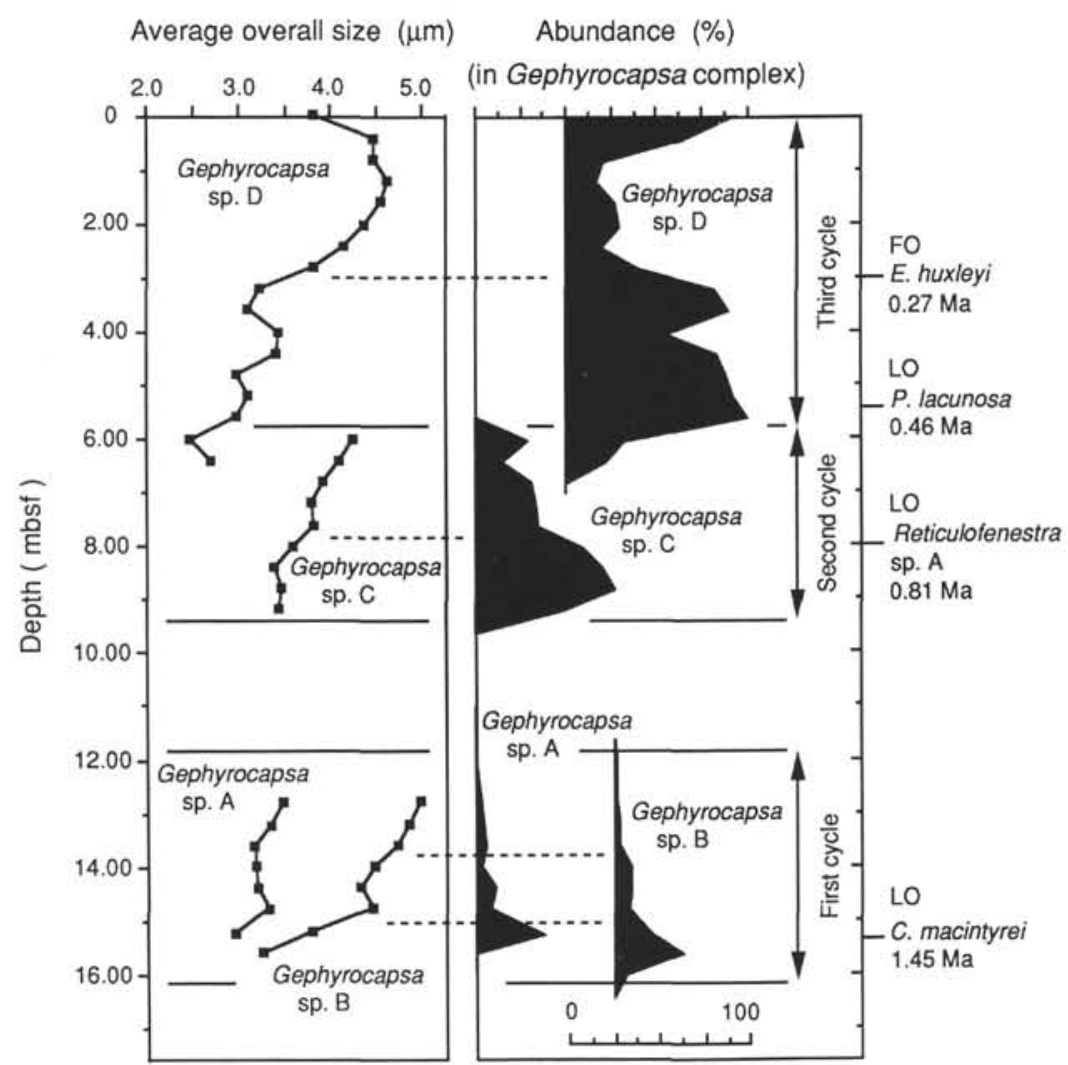

Figure 4. Stratigraphic changes in the average coccolith size (left column) and in percentage occurrence within the Gephyrocapsa complex (right column) of the four species of large Gephyrocapsa. The percentage abundance indicates the value within the total Gephyrocapsa complex. Dashed lines indicate the "transitional phases" of Gephyrocapsa sp. B, C, and D that showed evolutional size increase. Because large Gephyrocapsa are scarce in some samples, additional measurements were conducted to maintain the minimum amount of data. The minimum number of specimens measured for this plot is 50 for $\mathrm{Ge}$ phyrocapsa sp. B and 100 for Gephyrocapsa sp. C and D. Samples in which large Gephyrocapsa are exceedingly scarce were omitted in this figure.

5). This species became smaller and regained its abundance in the higher interval between 0.82 and 0.02 mbsf (Fig. 4). This change probably correlates with the simultaneous acme of $E$. huxleyi, and it is somewhat questionable to include these smaller specimens into Gephyrocapsa sp. D.

Specimens with an overall size of approximately $3 \mu \mathrm{m}$ and a small central opening appeared abruptly at 0.82 mbsf (Fig. 2); they were classified as Gephyrocapsa spp. (large). This is an event similar to the one observed at 12.02 mbsf (Fig. 2); these two events took place immediately above the climax in size increase of Gephyrocapsa sp. B and Gephyrocapsa sp. D, respectively (Fig. 4).

\section{Common Features of the Evolutional Cycles}

The observations mentioned in the sections on the first, second, and third cycles have revealed several common features among the morphometric changes of the three large Gephyrocapsa species, Gephyrocapsa sp. B, C, and D. These features are:

1. The early specimens of each species are fairly small, and clusters tend to overlap with small Gephyrocapsa in the coccolith-size/central-opening-size plot, resulting in a single large cluster (Fig. 2).

2. As each species becomes larger in an upward direction, the overlapping large cluster diverges into two separate clusters: large Gephyrocapsa and small Gephyrocapsa (Fig. 2). In the first and third cycles, small Gephyrocapsa decreased in average size while the sizes of Gephyrocapsa sp. B and D increased (Figs. 3 and 4).

3. The evolutional development of Gephyrocapsa sp. B, C, and $\mathrm{D}$ can be divided into early and late stages by abrupt changes in overall size as well as in abundance (Fig. 4). Each of the three species are smaller and generally more numerous within the $\mathrm{Ge}$ phyrocapsa complex during the early stages than in the late stages. This boundary is hereafter to be called the "transitional phase." The transitional phases of Gephyrocapsa sp. B, C, and $\mathrm{D}$ are located at 15.26-14.82, 8.02-7.62, and 3.22-2.88 mbsf, respectively (Fig. 4). In the case of Gephyrocapsa sp. B, an additional transitional phase was observed within the late stage between 14.02 and 13.62 mbsf.

4. The proportion of the central opening vs. coccolith size was constant within each cycle, measuring $31 \%, 34 \%$, and $37 \%$ for Gephyrocapsa sp. B, C, and D, respectively, and became larger in the later cycles (Fig. 6).

5 . The coccolith size of each species always starts at approximately $3 \mu \mathrm{m}$ in its evolutional size increase, and the early small forms of each cycle are clearly distinguished from the large forms of Gephyrocapsa spp. (small) (Figs. 2 and 4). This observation may indicate that each species of large Gephyrocapsa always evolved from a common ancestral stock with an overall approximate size of $3 \mu \mathrm{m}$. 

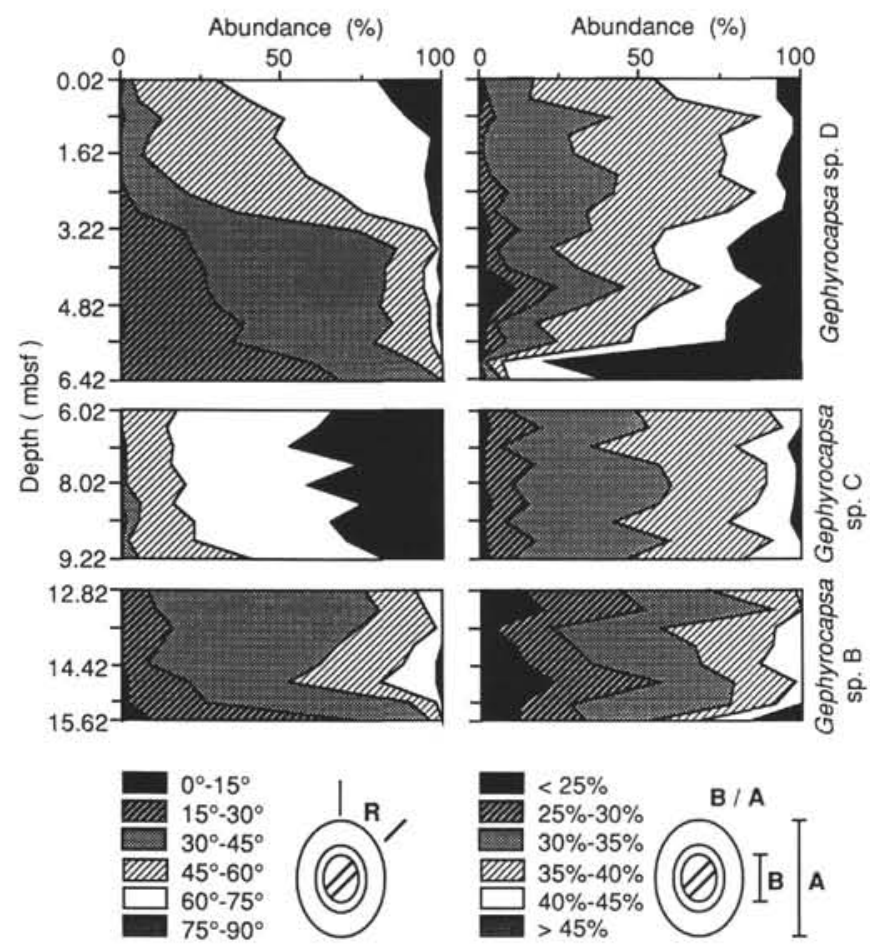

Figure 5. Stratigraphic changes in percentage abundances of the bridge angles (left column) and the proportion of central openings vs. coccolith sizes (right column) for the three large Gephyrocapsa species that showed time-progressive size increases.

\section{CORRELATION OF THE DATA OBSERVED TO THE EXISTING TAXONOMY AND BIOSTRATIGRAPHIC SCHEME}

\section{Gephyrocapsa protohuxleyi Complex}

Because its minute size makes it difficult to distinguish under a light microscope, morphometric variations and the stratigraphic occurrence of $G$. protohuxleyi had not been investigated in detail. In his original description of the species, McIntyre (1970) mentioned its phylogenic status as a transitional link between Emiliania huxleyi and the Gephyrocapsa complex. He identified its stratigraphic range from 0.095 to $1.20 \mathrm{Ma}$ and reported its abundant occurrences at near the Brunhes/Matuyama boundary as well as at a level close to the first appearance of $E$. huxleyi. Samtleben (1980) did not list G. protohuxleyi among his 11 Gephyrocapsa species. Matsuoka and Okada (1989) confirmed the prominent acme of $G$. protohuxleyi near the Brunhes/Matuyama boundary. Because the distal shield of $G$. protohuxleyi observed in this interval is formed with robust elements that lack the T-shaped configuration of a typical $G$. protohuxleyi that occurs in higher horizons, Matsuoka and Okada called this type "G. protohuxleyi" var. A.

As observed in Matsuoka and Okada (1989), the occurrence of $G$. protohuxleyi is also concentrated in two stratigraphic sequences at Hole 709C: in the interval between 11.62 and 6.02 mbsf where $G$. protohuxleyi var. A occurs, and in the interval between 2.42 and 0.82 mbsf where G. protohuxleyi (s. str.) occurs (Fig. 7). Gephyrocapsa protohuxleyi var. A, which seems unrelated to the evolution of $E$. huxleyi, is further subdivided into two morphotypes: (1) a type with high bridge angles and a large central opening that occurs in the interval between 11.62 and $7.62 \mathrm{mbsf}$, and (2) another type with low bridge angles that occurs in the level between 7.22 and $6.02 \mathrm{mbsf}$ (Fig. 7). The

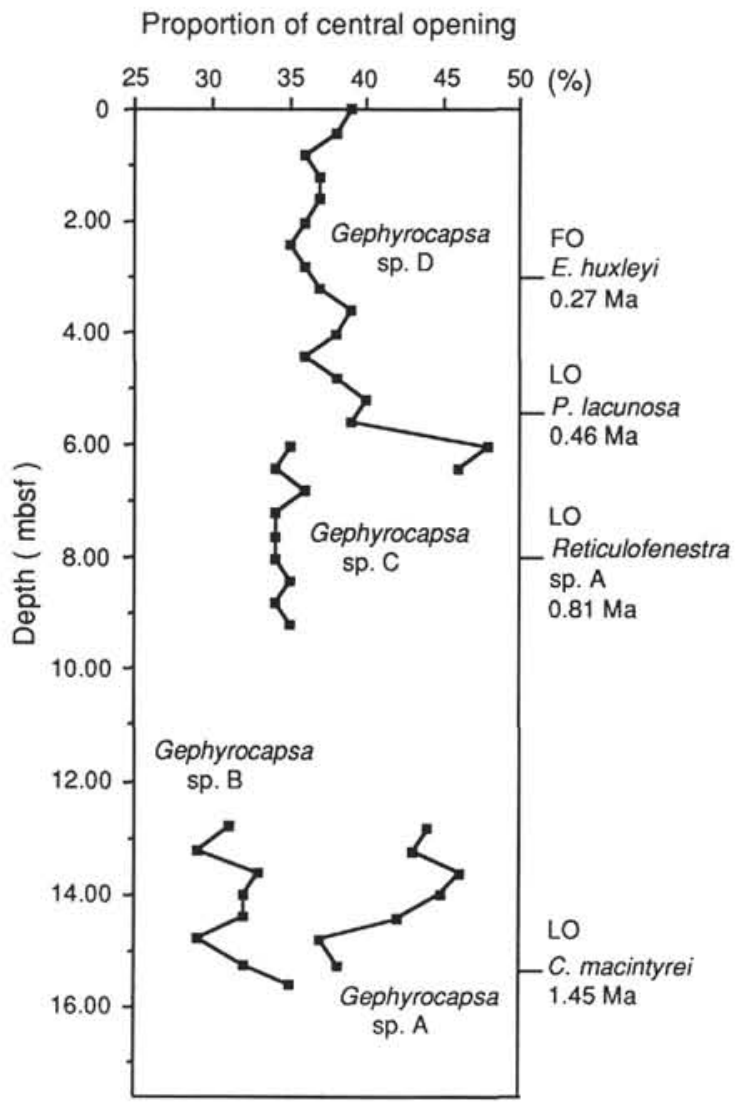

Figure 6. Stratigraphic changes in the averaged proportion of the central openings of the four large Gephyrocapsa species.

acme of the latter type is consistent with that found by Matsuoka and Okada (1989) (Fig. 8).

Specimens with no slits on the distal shield and a notched periphery occur between 7.22 and 6.02 mbsf. These specimens are similar to $G$. protohuxleyi var. A except for the absence of slits on the distal shield. Because their occurrence exactly corresponds with that of $G$. protohuxleyi var. A, these specimens are probably a variation of G. protohuxleyi var. A. Gephyrocapsa protohuxleyi (s. str.) is morphologically similar to $E$. huxleyi except for the presence of a bridge. Since its stratigraphic occurrence is very close to the evolutional development of E. huxleyi (Fig. 8), there is little doubt regarding the direct phylogenic relations between these two taxa.

Slits on the distal shield are also found among the large forms of Gephyrocapsa. These large slitted forms were not differentiated from the usual types of large Gephyrocapsa in the previous discussions. The exclusive plot of the slitted large forms exhibits two peaked occurrences that correspond to the incipient stages of Gephyrocapsa sp. B and C (Figs. 7 and 8). The reason why these slits develop is unknown, but evidence indicates a morphologic instability in the Gephyrocapsa complex during the early stages of its evolutional cycles.

\section{Gephyrocapsa caribbeanica Complex}

The classification of $G$. caribbeanica is in considerable confusion, and two contradicting definitions have been commonly used. These criteria identify the species by (1) the presence of a small central opening that often shows irregular periphery or (2) a low bridge angle. In Hole $709 \mathrm{C}$, specimens assignable to the four large Gephyrocapsa species that fit the first criterion mainly occur in three intervals (Fig. 7). These intervals seem to corre- 


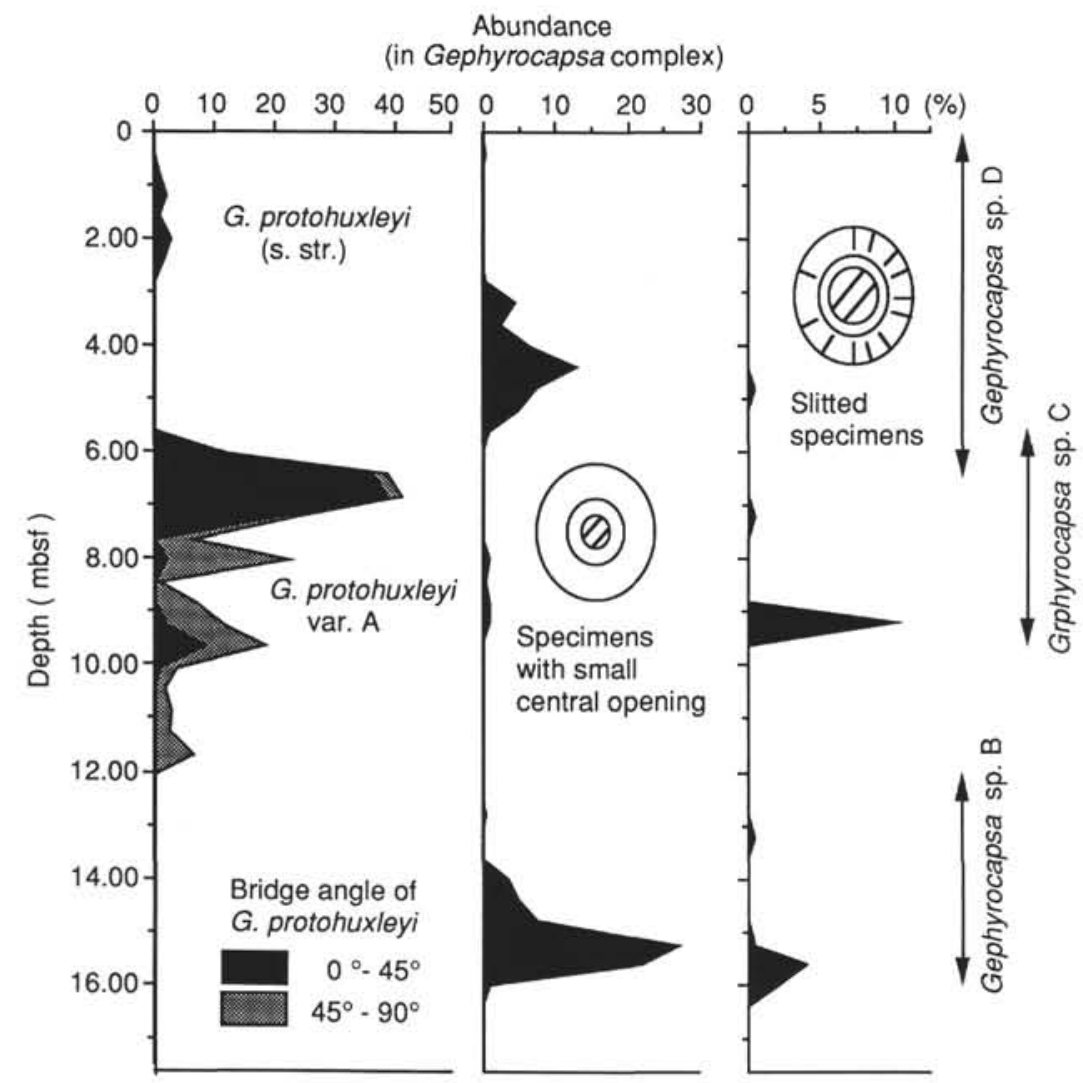

Figure 7. Stratigraphic occurrences of Gephyrocapsa protohuxleyi (left column), large Gephyrocapsa with a very small central opening (center column), and large Gephyrocapsa with slits on the distal disc (right column). Plots are expressed in percentage abundances in the total Gephyrocapsa complex. These specimens were included in the normal specimens of the respective categories in other figures.

spond to the early stages of the three evolutional cycles as well as to the acme of the large Gephyrocapsa that has slits on its distal discs (Figs. 4 and 7). In this interpretation, G. caribbean$i c a$, as defined by the first criterion, is an end member of the morphometric variations developed during the early stages of the evolutional cycles. Specimens identifiable as $G$. caribbean$i c a$, according to the second criterion (i.e., bridge angle), occur in most of the intervals. In particular, almost all Gephyrocapsa sp. B and early forms of Gephyrocapsa sp. D would fit into this category.

No matter which criterion we adopt, there are many intermediate forms with no clear breaking points. Therefore, it is extremely difficult to differentiate $G$. caribbeanica as an independent taxon in quantitative analyses of the Gephyrocapsa complex. Accordingly, the FO of G. caribbeanica, which was defined as the base of Subzone CN13b (Bukry, 1973; Okada and Bukry, 1980), should correspond to the beginning of the first evolutional cycle.

As mentioned in Matsuoka and Okada (1989), the original definition (Bukry, 1973) of the Zone CN13/CN14 boundary corresponds to the rejuvenation of $G$. oceanica, which occurred at the top of the Jaramillo Event. This is the same event discussed here as the start of the second cycle, although no magnetic data are available for Hole 709C.

\section{The "Small Gephyrocapsa Zone"}

Gartner (1977) identified a biostratigraphically useful middle Pleistocene event in which small Gephyrocapsa predominate the nannoflora. The "small Gephyrocapsa zone" of Gartner was defined as an interval between the last appearance datum (LAD) of Helicosphaera sellii and the end of the small Gephyrocapsa acme. Because $H$. sellii is rare and sporadic in many sections, a common practice for many biostratigraphers in identifying the "small Gephyrocapsa zone" is to substitute the original definition by the almost complete absence of large Gephyrocapsa.

In Hole 709C, we made the following observations:

1. The acme of small Gephyrocapsa occurs at several intervals throughout the Pleistocene, although the most significant one did occur during the later part of the early Pleistocene (Fig. 9).

2. The most significant acme of small Gephyrocapsa does not precisely correspond to the temporal disappearance of large Gephyrocapsa (Fig. 9). The exact beginning of this acme is difficult to pinpoint, but its top was observed in the interval between 10.42 and 10.02 mbsf. The base of the almost complete temporal disappearance of large Gephyrocapsa, which corresponds to the LO of Gephyrocapsa sp. B, is detected at 12.02 mbsf, whereas its top, the FO of Gephyrocapsa sp. C, is identifiable at 9.62 mbsf.

3. This significant acme of small Gephyrocapsa is also characterized by the abundant occurrence of high-bridge-angled small Gephyrocapsa, which are totally absent or rare in other intervals (Fig. 9).

It is not yet clear what caused the peculiar flora of the "small Gephyrocapsa zone." Gartner (1988) hypothesized that it was an intensified equatorial upwelling caused by a sudden change 


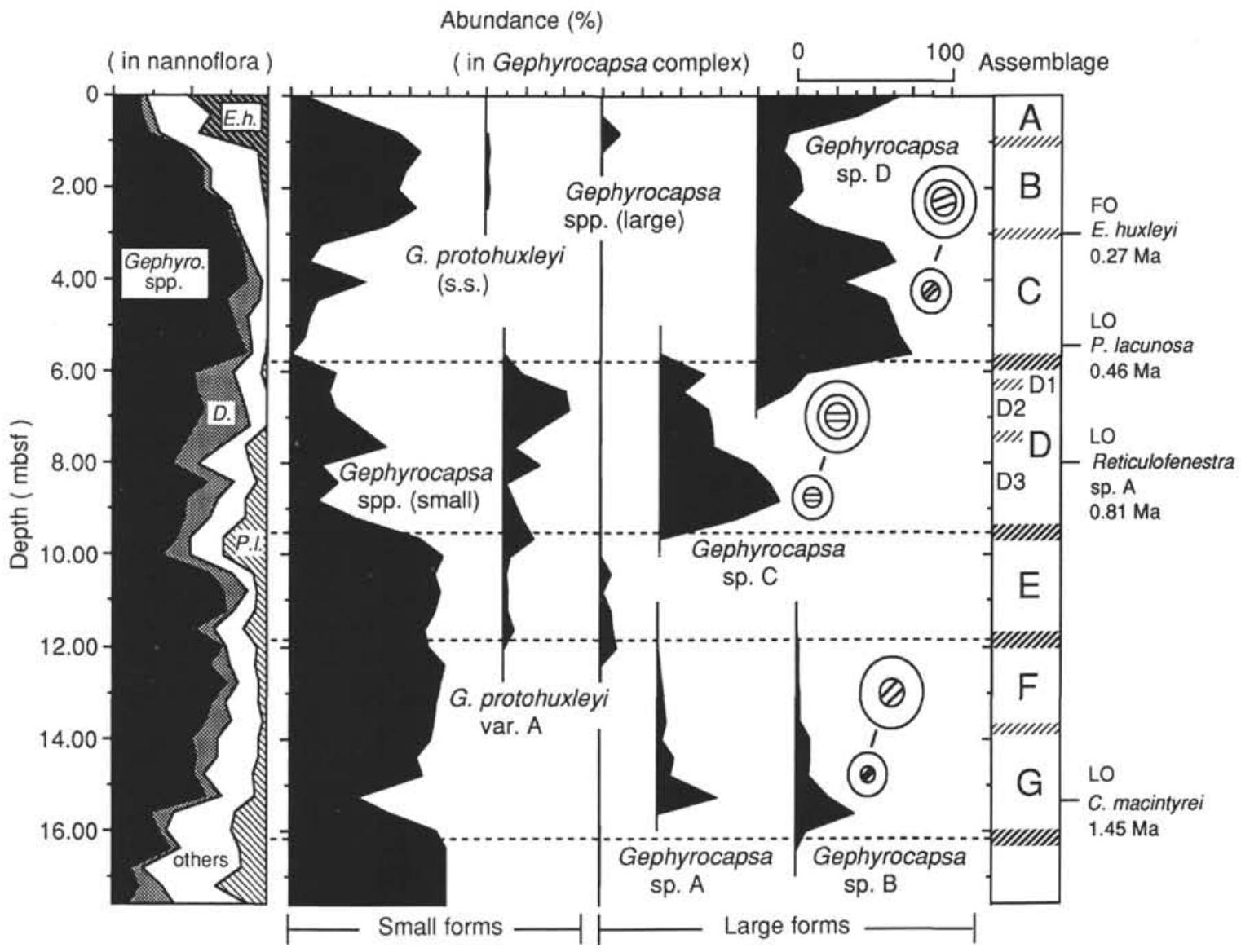

Figure 8. Stratigraphic change of nannoflora and the percentage abundance of each Gephyrocapsa taxon within the total Gephyrocapsa complex. E.h. = Emiliania huxleyi, D. = Dictyococcites spp., and P.l. = Pseudoemiliania lacunosa .

in ocean circulation. The occurrence of large forms at Site 709C is similar to the one observed in the northwestern Pacific Ocean (Matsuoka and Okada, 1989). We have observed in both oceans that the decline of small Gephyrocapsa is not always accompanied by an increase of large Gephyrocapsa or vice versa (Fig. 9). This observation implies mutually independent causes for the changes in abundance of small and large Gephyrocapsa.

\section{Relationship to Previously Defined Taxa of Gephyrocapsa}

The main criteria for the classification of Gephyrocapsa are (1) the overall size of the coccolith, (2) the proportion of the central opening, and (3) the shape and angle of the central bridge. Observations throughout this investigation have revealed the continuous morphologic development of the Gephyrocapsa taxon and the existence of morphologically diverse variations within the Gephyrocapsa complex. It is difficult, therefore, to correlate precisely some of the existing taxa to the various forms observed here. The following are examples of possible correlations between some important taxa and the quantitatively identified forms.

Early forms of Gephyrocapsa sp. B, C, and D that showed evolutional size increase were not morphologically distinct, and they were probably identified as $G$. oceanica, Gephyrocapsa caribbeanica, or small Gephyrocapsa, depending upon who the observers were. Well-developed late forms of Gephyrocapsa sp. $\mathrm{B}, \mathrm{C}$, and D can be assigned to the existing taxa. The late form of Gephyrocapsa sp. B corresponds to Gephyrocapsa lumina Bukry (1973), G. oceanica sp. 1 and sp. 2 of Rio (1982), and $G$. oceanica (large) and $G$. caribbeanica (large) of Takayama and Sato (1986). Gephyrocapsa sp. C, which has high bridge angles, can be identified as G. oceanica rodela Samtleben (1980), Gephyrocapsa omega Bukry (1973), and G. oceanica sp. 3 of Rio (1982). Gephyrocapsa parallela of Takayama and Sato (1986) corresponds to Gephyrocapsa sp. C and the late forms of $\mathrm{Ge}$ phyrocapsa sp. D. The original G. parallela Hay and Beaudry (1973) is likely to correspond to the late forms of Gephyrocapsa sp. D.

Most researchers separate small forms from large forms within the Gephyrocapsa complex, but there is no common criterion for the exact boundary between them. Matsuoka and Okada (1989), Gartner (1988), Rio (1982), and Takayama and Sato (1986) set the boundaries at $2.5,3,3.5$, and $4 \mu \mathrm{m}$, respectively. For biostratigraphic studies that use light microscopes, 3 $\mu \mathrm{m}$ is easier to apply than $2.5 \mu \mathrm{m}$ as the cut-off point. As shown in Fig. 2, numerous specimens range from 3 to $4 \mu \mathrm{m}$ in overall size, and, therefore, a boundary of 3.5 or $4.0 \mu \mathrm{m}$ seems unfitted to identify the large forms. A minimal size of $4 \mu \mathrm{m}$ for large forms, meanwhile, is useful for biostratigraphy because specimens that are larger than $4 \mu \mathrm{m}$ occur only in limited intervals.

\section{TIME-PROGRESSIVE CHANGES IN QUATERNARY NANNOFLORA}

Matsuoka and Okada (1989) identified six floral assemblages (Assemblages A-F) within the last $1.3 \mathrm{~m} . \mathrm{y}$. in the subtropical northwestern Pacific Ocean. These assemblages are mainly based on relative abundances of various morphotypes within the $\mathrm{Ge}$ - 


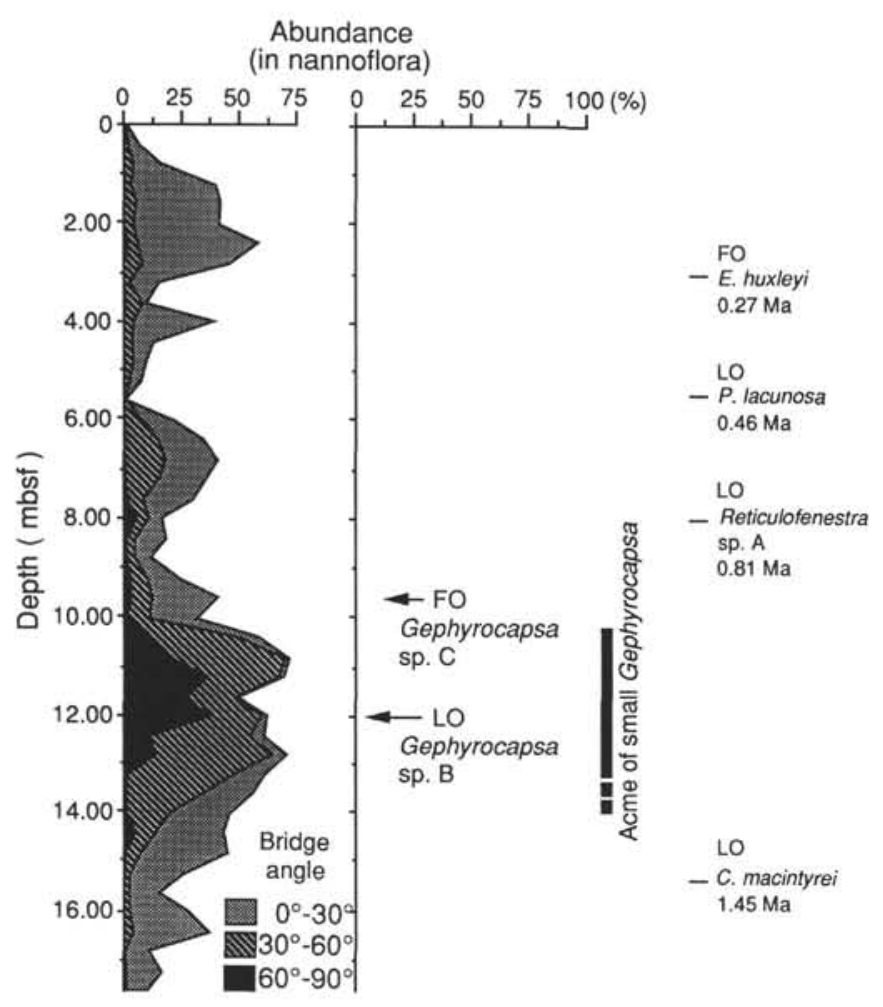

Figure 9. Stratigraphic occurrences in the abundance of all small Gephyrocapsa (left column) and of Gephyrocapsa sp. A, B, C, and D combined (right column). Data are expressed as percentage abundances within the total nannoflora. Small Gephyrocapsa were subdivided into three categories according to the bridge-angle difference; the legend for the filled patterns is exclusively for small Gephyrocapsa.

phyrocapsa complex, and the defining criteria for these assemblages are convertible to the modified classification employed here (Fig. 10).

Assemblage A, defined by the dominant occurrence of Emiliania huxleyi, occurs in the top three samples taken at 0.02 , 0.42 , and $0.82 \mathrm{mbsf}$ (Fig. 8). Assemblage B, characterized by the common occurrence of $E$. huxleyi and various forms of $\mathrm{Ge}$ phyrocapsa, was identified between 1.22 and 2.82 mbsf, which corresponds to the middle upper part of the range of Gephyrocapsa sp. D (Fig. 8). Assemblage C, characterized by the dominant occurrence of medium-sized $G$. oceanica, occurs between 3.22 and $5.62 \mathrm{mbsf}$ and corresponds to the early stage of $\mathrm{Ge}$ phyrocapsa sp. D.

The presence of Subassemblage D1, in which large Gephyrocapsa with high bridge angles are dominant, is rather obscure in Hole $709 \mathrm{C}$. The flora observed at 6.02 mbsf probably corresponds to this subassemblage. Subassemblage D2, defined by the dominant occurrence of G. protohuxleyi var. A, is identifiable in the interval between 6.42 and 7.22 mbsf. Subassemblages D1 and D2 correspond to the upper range of Gephyrocapsa sp. C. Subassemblage D3, characterized by abundant Gephyrocapsa with medium sizes and high bridge angles, was observed between 7.62 and 9.62 mbsf. This subassemblage corresponds to the lower range of Gephyrocapsa sp. C. Assemblage E, distinguished by the almost complete absence of large Gephyrocapsa, is identified between 10.02 and 11.62 mbsf. Assemblage F, characterized by the common occurrence of very large Gephyrocapsa, corresponds to the interval between 12.02 and 13.62 mbsf.

An additional floral assemblage was observed between 14.02 and 16.02 mbsf (Figs. 8 and 10). Because of the lack of core

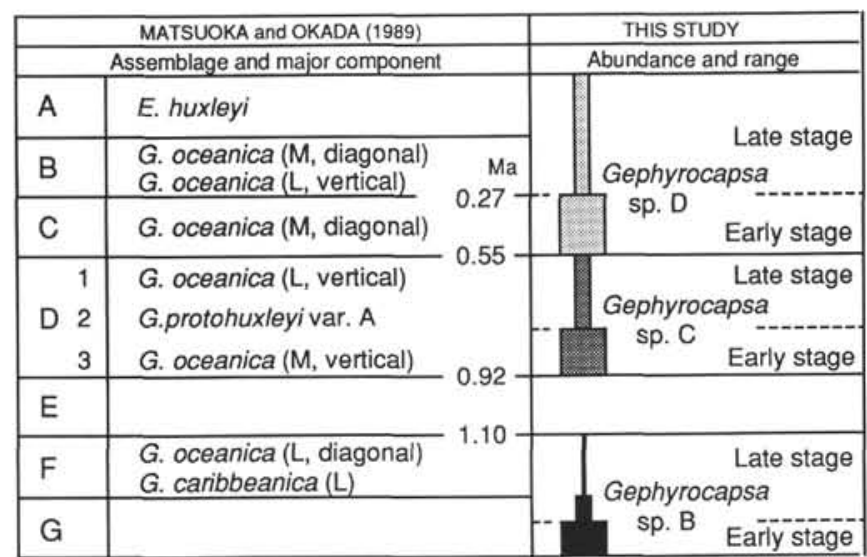

Figure 10. Correlation of assemblage zones with the stratigraphic ranges of the three large Gephyrocapsa species that showed evolutional size increase.

penetration for the sample they studied, Matsuoka and Okada (1989) could not observe this assemblage. The assemblage, which is newly identified as Assemblage G, is characterized by the absence of very large Gephyrocapsa and by the abundant occurrence of medium-sized Gephyrocapsa with moderate bridge angles (Fig. 9). Specimens with small central openings are also abundant in this new assemblage. The basal occurrence of Assemblage $\mathrm{G}$ is marked by the first appearance of Gephyrocapsa sp. B.

The boundaries between the floral assemblages defined by Matsuoka and Okada (1989) correspond well to the incipient and terminal phases as well as to the "transitional phases" of the three specimens of large Gephyrocapsa (Figs. 4 and 10). Because boundary criteria for the floral assemblages and the evolutional phases are defined by the significant changes in the $\mathrm{Ge}$ phyrocapsa complex, this finding is no surprise. However, it does indicate that stratigraphic changes in the Gephyrocapsa complex occurred in a similar mode between the tropical Indian Ocean and the subtropical northwestern Pacific Ocean.

Although the succession of floral assemblages are similar, some differences in floral composition were noticed between these two oceans. First, small forms of Gephyrocapsa (excluding $G$. protohuxleyi) are more abundant throughout the Quaternary sequence in Hole $709 \mathrm{C}$ than in the Pacific core. In addition, several reports have been given that imply environmental controls over the morphology of Gephyrocapsa species (i.e., Bukry, 1973; Geitzenauer et al., 1976, 1977; Roth and Coulbourn, 1982). In these reports, specimens with high-angled bridges were found abundantly in low latitudes, whereas specimens with low-angled bridges were more common in high latitudes. Furthermore, the time intervals in which Gephyrocapsa with high-angled bridges occur abundantly (around 0.9-0.5 Ma and $0.3 \mathrm{Ma}$ to the Present) are much longer than the glacial-interglacial cycle, which is the most likely controlling factor of ocean environment. Aside from the possible influence of intensified upwelling resulting in Assemblage E (flora of the "small Gephyrocapsa zone"), the time-progressive morphological changes observed in this investigation are likely to be evolutional events.

\section{SUMMARY}

The purpose of the present investigation was to study quantitatively the time-progressive changes in morphometry and floral composition of the Gephyrocapsa complex. The present classification of the Gephyrocapsa complex, which was established mainly from the biostratigraphic viewpoint and has proven to be 
useful for that purpose, cannot be used to describe our species, which represent evolutional lineages. Consequently, only one established species (Gephyrocapsa protohuxleyi) that is easily identifiable without any confusion was employed, and four large species (Gephyrocapsa sp. A, B, C, and D) were newly created to describe our results. The results of our investigation of the Quaternary sequence of Hole 709C into the morphometric changes in the Gephyrocapsa complex as well as into the stratigraphic changes in the nannoflora can be summarized as follows:

1. Small and large Gephyrocapsa were recognizable within the Gephyrocapsa complex, but we demonstrated that separation of Gephyrocapsa specimens into these groups by coccolith size alone is not pragmatic for a phylogenetic study of this complex.

2. The small Gephyrocapsa were further subdivided into groups of Gephyrocapsa protohuxleyi and all other small Gephyrocapsa. The former species was subdivided into two varieties that occupy completely isolated stratigraphic ranges. The earlier variety showed good potential for biostratigraphy.

3. Four species, Gephyrocapsa sp. A, B, C, and D, were identified within the large Gephyrocapsa, and the latter three were found to become progressively larger.

4. Gephyrocapsa sp. B and C disappeared abruptly after reaching their maximum sizes. Thus, three cycles of morphologic development were distinguishable. These cycles occurred in the following time intervals: the first cycle was found in $\mathrm{Ge}$ phyrocapsa sp. B around 1.6-1.1 Ma; the second cycle was found in Gephyrocapsa sp. C around 0.9-0.5 Ma; and the third cycle was found in Gephyrocapsa sp. D from $0.5 \mathrm{Ma}$ to the present.

5. The abundance of Gephyrocapsa sp. B, C, and D in each evolutional cycle decreased as their overall sizes increased, and the stratigraphic ranges of each species can be divided into early and late intervals based on changes in their overall sizes and relative abundance.

6. Six assemblages (Assemblages A-F) identified in the subtropical Pacific Ocean can be applied to the Quaternary nannoflora of Hole $709 \mathrm{C}$ in the tropical Indian Ocean, and a new assemblage (Assemblage G) was proposed in the lowest Pleistocene below Assemblage F.

\section{ACKNOWLEDGMENTS}

The Leg 115 scientific party and technical staff tolerated the extensive sampling from the Quaternary cores of Leg 115. Hans Thierstein and an anonymous reviewer provided us with valuable criticism and helpful advice. We are truly grateful to these people.

\section{REFERENCES}

Bukry, D., 1973. Coccolith stratigraphy, eastern equatorial Pacific, Leg 16 Deep Sea Drilling Project. In Andel, T. H., Heath, G. R., et al., Init. Repts. DSDP, 16: Washington (U.S. Govt. Printing Office), 653-711.

Gartner, S., Jr., 1977. Calcareous nannofossil biostratigraphy and revised zonation of the Pleistocene. Mar. Micropaleontol., 2:1-25. 1988. Paleoceanography of the mid-Pleistocene. Mar. Micropaleontol., 13:23-46.

Geitzenauer, K. R., Roche, M. B., and McIntyre, A., 1976. Modern Pacific coccolith assemblages: derivation and application to late Pleistocene paleotemperature analysis. In Cline, R. M., and Hays, J. D. (Eds.), Investigation of Late Quaternary Paleoceanography and Paleoclimatology. Mem. Geol. Soc. Am., 145:423-448.

1977. Coccolith biogeography from North Atlantic and $\mathrm{Pa}$ cific surface sediments. In Ramsay, A.T.S. (Ed.), Oceanic Micropaleontology: New York (Academic Press), 973-1008.

Hay, W. W., and Beaudry, F. M., 1973. Calcareous nannofossils-Leg 15, Deep Sea Drilling Project. In Edgar, N. T., Saunders, J. B., et al., Init. Repts. DSDP, 15: Washington (U.S. Govt. Printing Office), 625-683.

Matsuoka, H., and Okada, H., 1989. Quantitative analysis of Quaternary nannoplankton in the subtropical northwestern Pacific Ocean. Mar. Micropaleontol., 14:97-118.

McIntyre, A., 1970. Gephyrocapsa protohuxleyi sp. n.: a possible phylogenic link and index fossil for the Pleistocene. Deep-Sea Res., 17: $187-190$.

Okada, H., and Bukry, D., 1980. Supplementary modification and introduction of code numbers to the low-latitude coccolith biostratigraphic zonation (Bukry, 1973; 1975). Mar. Micropaleontol., 5:321325 .

Rio, D., 1982. The fossil distribution of Coccolithophore genus Gephyrocapsa Kamptner and related Plio-Pleistocene chronostratigraphic problems. In Prell, W. L., Gardner, J. V., et al., Init. Repts. DSDP, 68: Washington (U.S. Govt. Printing Office), 325-343.

Rio, D., Backman, J., and Raffi, I., in press. Calcareous nannofossil biochronology and the Pliocene/Pleistocene boundary: the Neogene/ Quaternary boundary. IGCP Proj., Final Rep., No. 41.

Roth, P. H., and Coulbourn, W. T., 1982. Floral and solution patterns of coccoliths in surface sediments of the North Pacific. Mar. Micropaleontol., 7:1-52.

Samtleben, C., 1980. Die Evolution der Coccolithophoriden-Gattung Gephyrocapsa nach Befunden im Atlantik. Paläontol. Z., 54:91-127.

Takayama, T., and Sato, T., 1986. Coccolith biostratigraphy of the North Atlantic Ocean, Deep Sea Drilling Project Leg 94. In Ruddiman, W. F., Kidd, R. B., Thomas, E., et al., Init. Repts. DSDP, 94, Pt. 2: Washington (U.S. Govt. Printing Office), 651-702.

\section{Ms 115B-155}

Date of initial receipt: 26 May 1989

Date of acceptance: 26 October 1989 


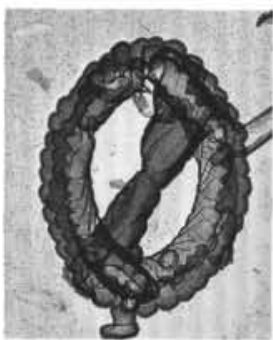

1

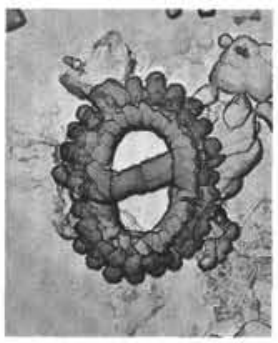

6

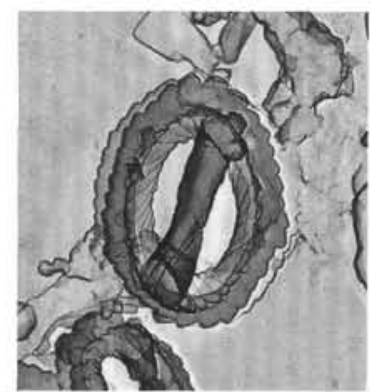

11

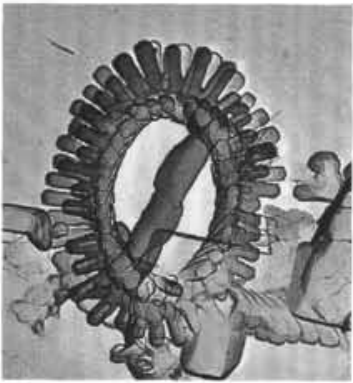

15

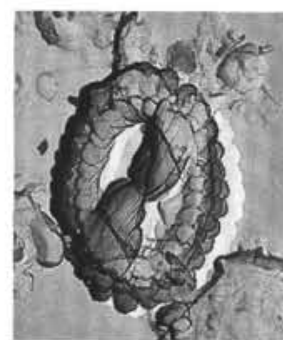

2

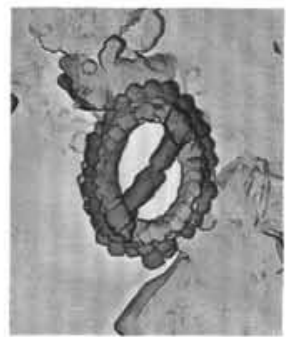

7

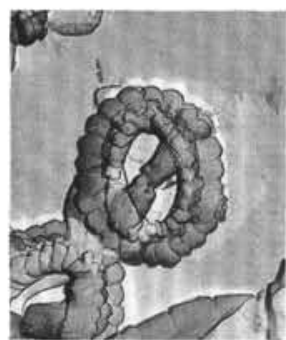

3

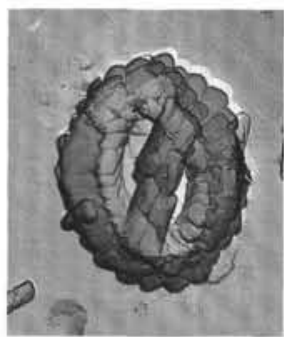

8

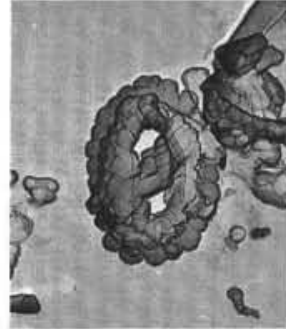

4

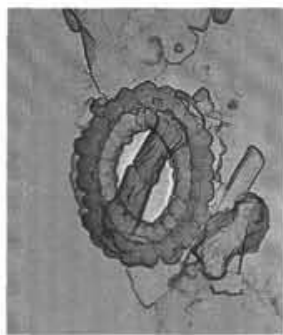

9

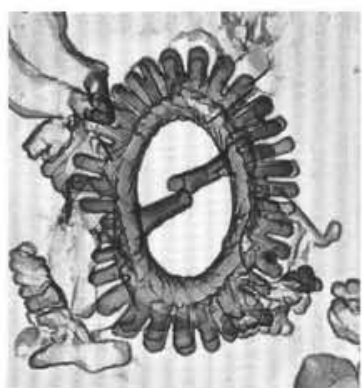

13

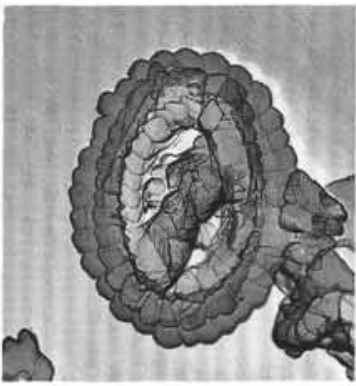

17

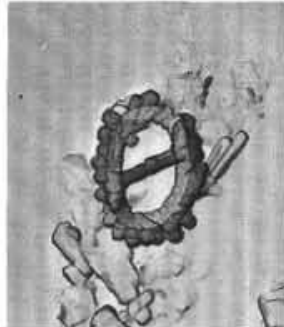

5

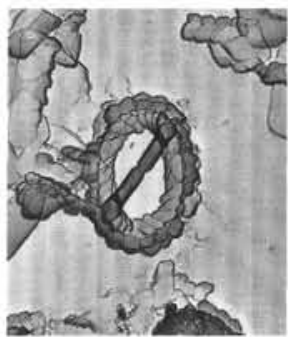

10

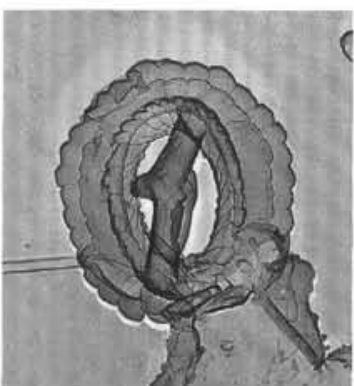

12

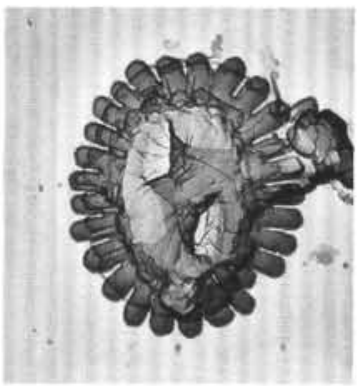

16

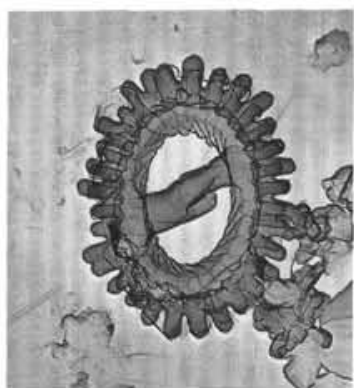

14

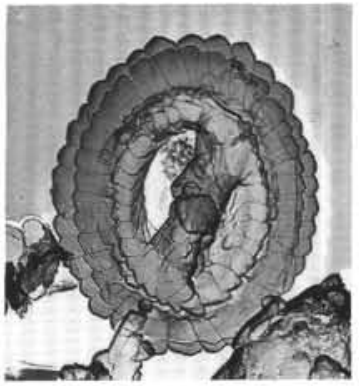

18

Plate 1. Transmission electron micrographs. All figures have the same magnification. The scale bar in the lower right corner represents $3 \mu \mathrm{m}$. 1-12. Gephyrocapsa spp. (small). 1 and 2, Sample 115-709C-3H-1, 142-143 cm (16.82 mbsf); 3 and 4, Sample 115-709C-2H-5, 142-143 cm (13.22 mbsf); 5 and 6, Sample 115-709C-2H-4, 132-133 cm (11.62 mbsf); 7, Sample 115-709C-2H-3, $42-43 \mathrm{~cm}$ (9.22 mbsf); 8, Sample 115-709C-2H-1, $62-63 \mathrm{~cm}$ (6.42 mbsf); 9, 11, and 12, Sample 115-709C-1H-2, 92-93 cm (2.42 mbsf); and 10, Sample 115-709C-1H-1, 122-123 cm (1.22 mbsf). 13-16. Gephyrocapsa protohuxleyi var. A. 13, Sample 115-709C-2H-3, $42-43 \mathrm{~cm}$ (9.22 mbsf); 14, Sample $115-709 \mathrm{C}-2 \mathrm{H}-2,72-73 \mathrm{~cm}(8.02 \mathrm{mbsf})$; 15, Sample 115-709C-2H-1, 102-103 cm (6.82 mbsf); 16, Sample 115-709C-2H-1, 22-23 cm (6.02 mbsf). 17-18. Gephyrocapsa sp. A. Sample $115-709 \mathrm{C}-2 \mathrm{H}-6,32-33 \mathrm{~cm}(13.62 \mathrm{mbsf})$ 


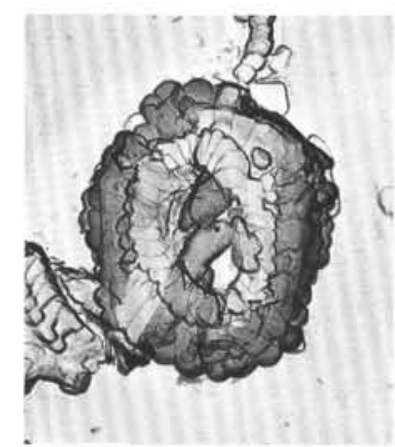

1

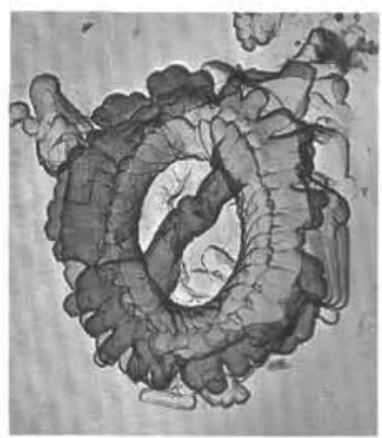

5

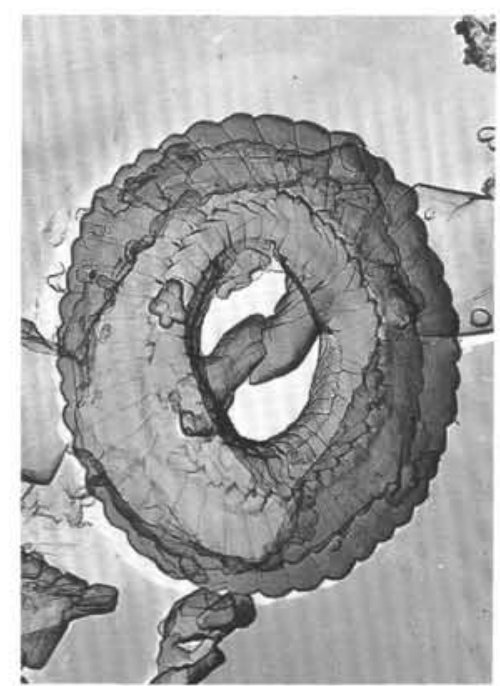

9

2

6
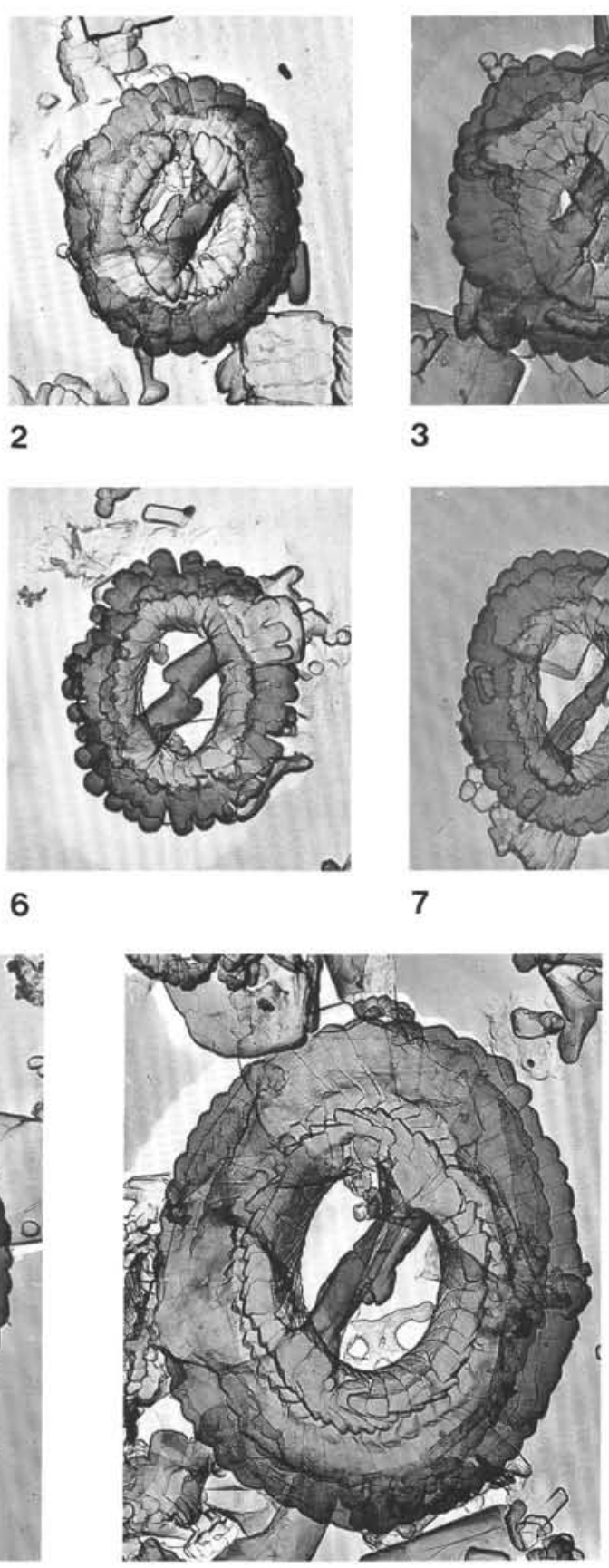

10

3

7
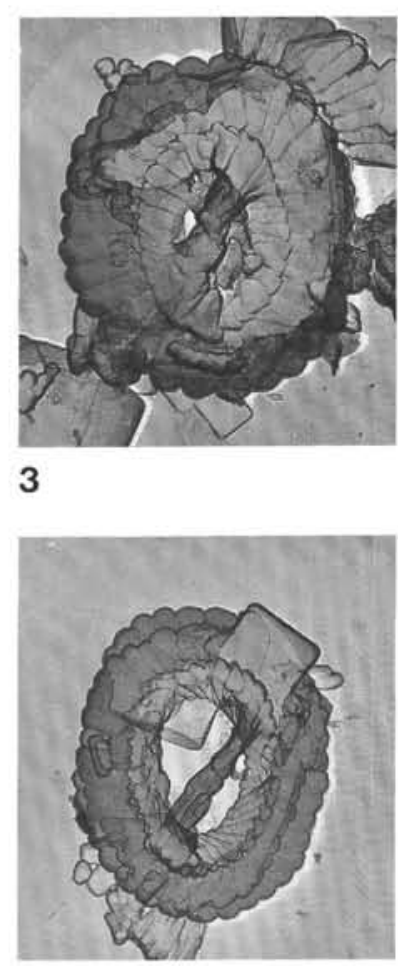

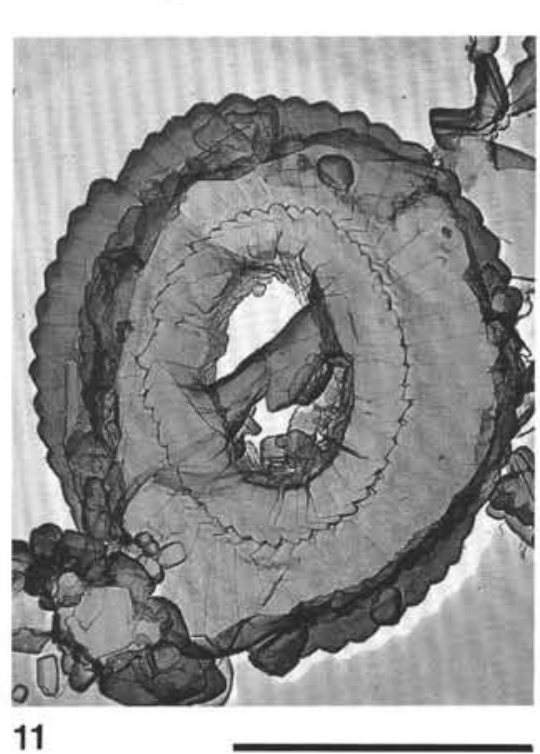

11

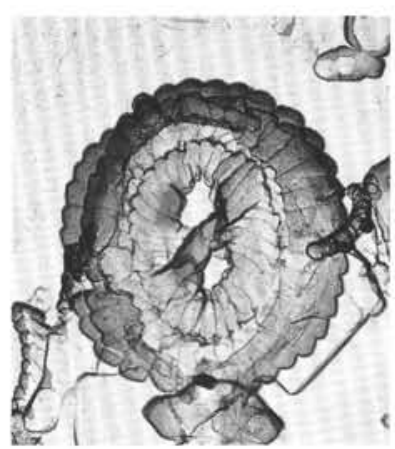

4

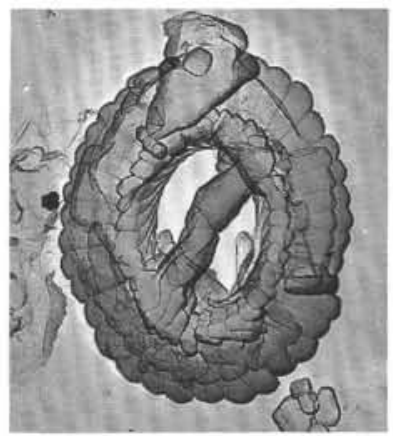

8

Plate 2. Transmission electron micrographs. All figures have the same magnification. The scale bar in the lower right corner represents $3 \mu \mathrm{m}$. 1-11. Gephyrocapsa sp. B. 1-4, Sample 115-709C-3H-1, 22-23 cm (15.62 mbsf); 5 and 6, slitted specimen, Sample 115-709C-3H-1, 22-23 cm (15.62 mbsf); 7 and 8, Sample 115-709C-2H-7, 2-3 cm (14.82 mbsf); 9 and 10, Sample 115-709C-2H-6, 32-33 cm (13.62 mbsf); and 11, Sample $115-709 \mathrm{C}-2 \mathrm{H}-5,62-63 \mathrm{~cm}(12.42 \mathrm{mbsf})$. 


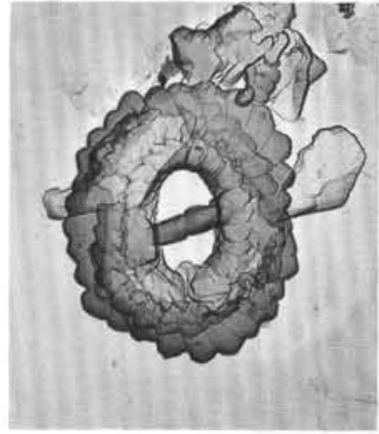

1

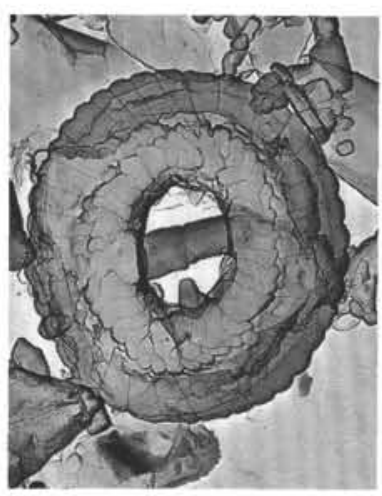

5

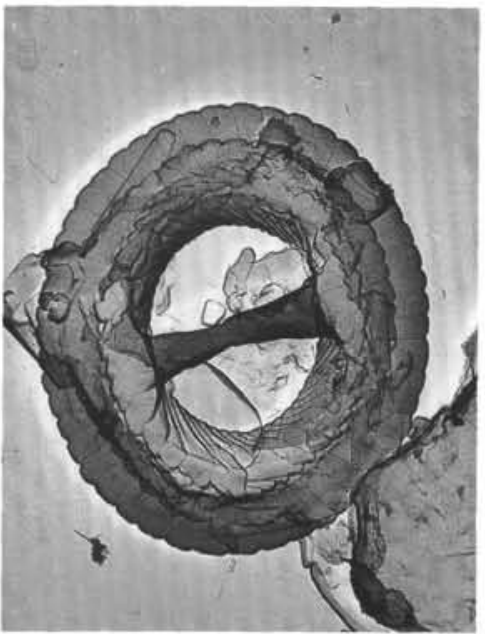

9

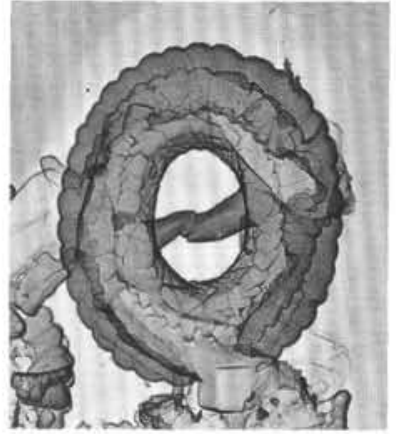

2

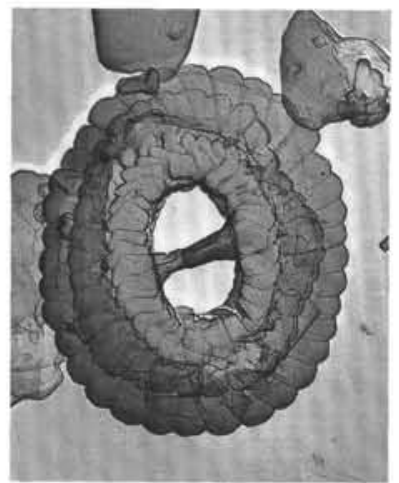

6

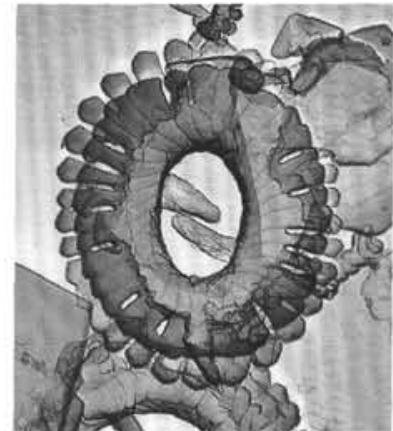

3

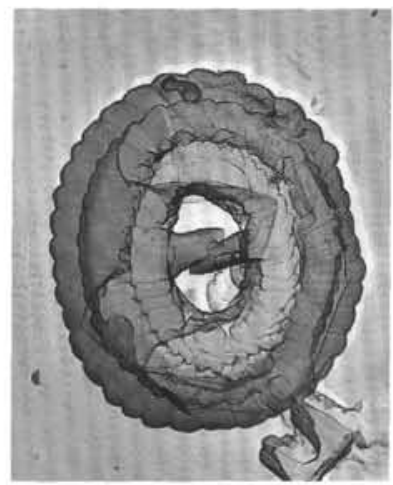

7

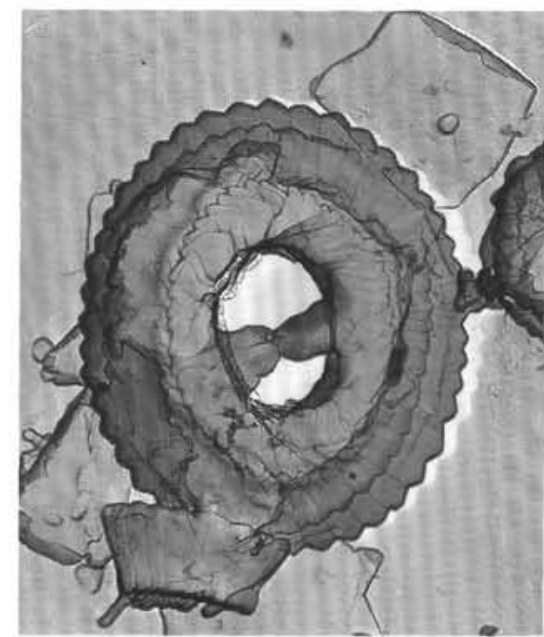

10

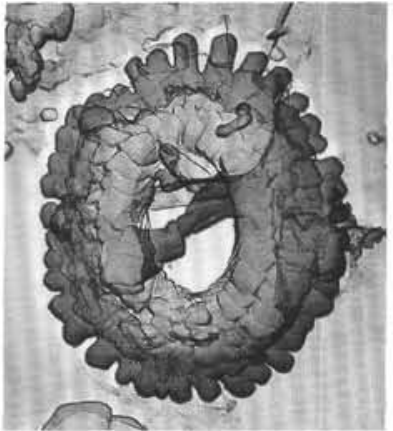

4

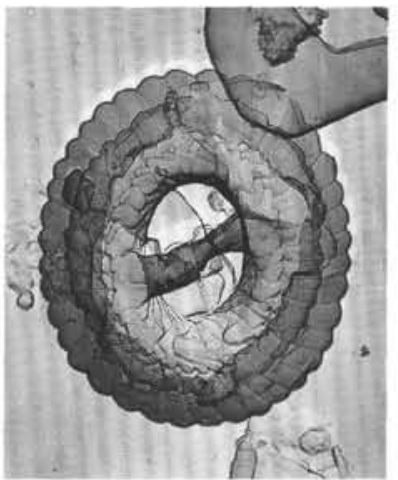

8

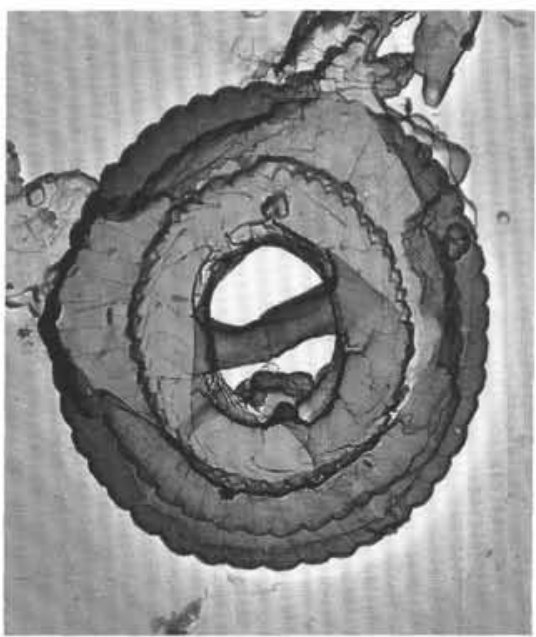

11

Plate 3. Transmission electron micrographs. All figures have the same magnification. The scale bar in the lower right corner represents $3 \mu \mathrm{m}$. 1-11. Gephyrocapsa sp. C. 1, 2, and 5, Sample 115-709C-2H-3, $42-43 \mathrm{~cm}(9.22 \mathrm{mbsf}) ; 3$ and 4, slitted specimen, Sample 115-709C-2H-3, 42-43 cm (9.22 mbsf); 6-8, Sample 115-709C-2H-2, 72-73 cm (8.02 mbsf); 9, Sample 115-709C-2H-1, 102-103 cm (6.82 mbsf); 10, Sample 115-709C-2H-1, $62-63 \mathrm{~cm}$ (6.42 mbsf); 11 , Sample $115-709 \mathrm{C}-2 \mathrm{H}-1,22-23 \mathrm{~cm}$ (6.02 mbsf). 


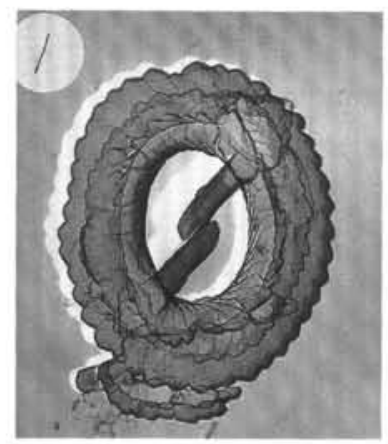

1

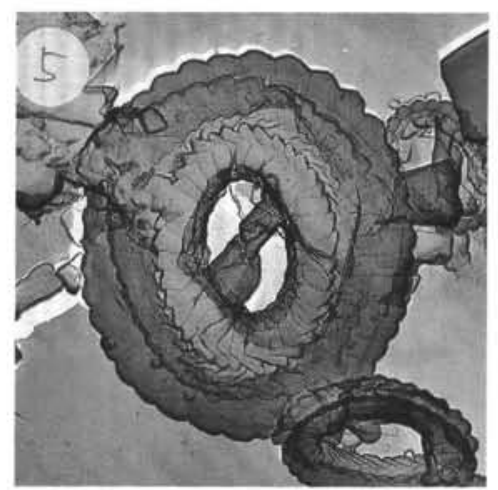

5

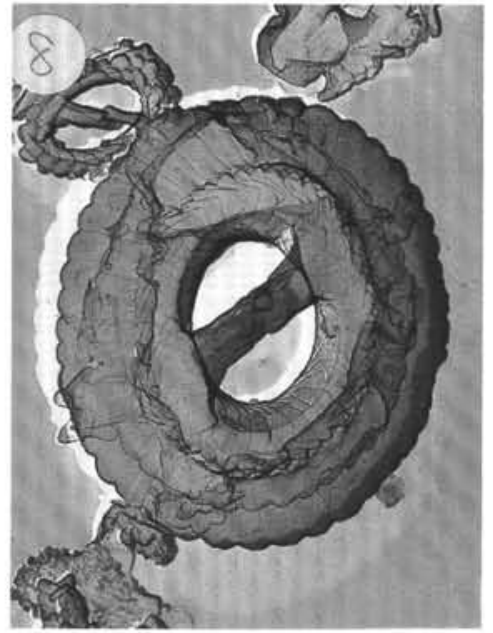

8

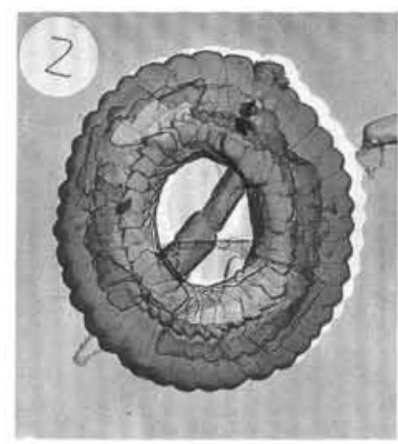

2

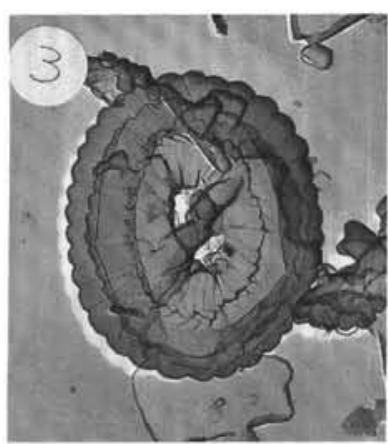

3

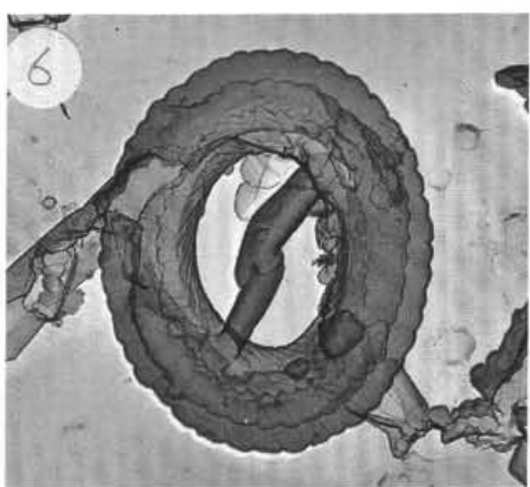

6

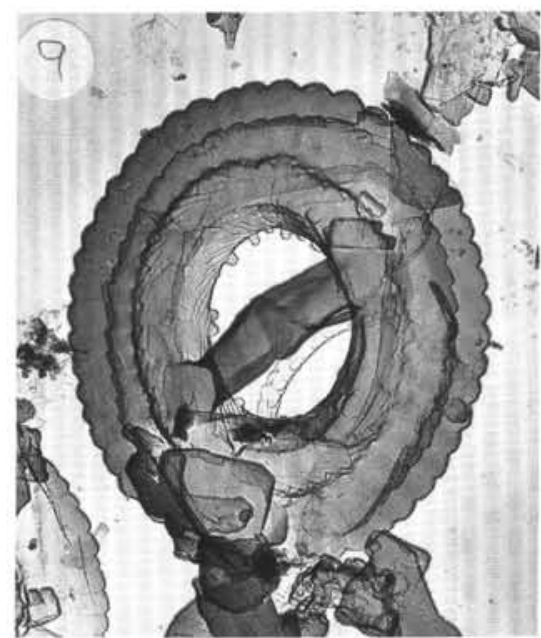

9

7

10

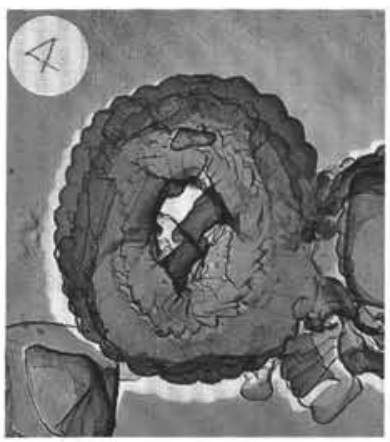

4
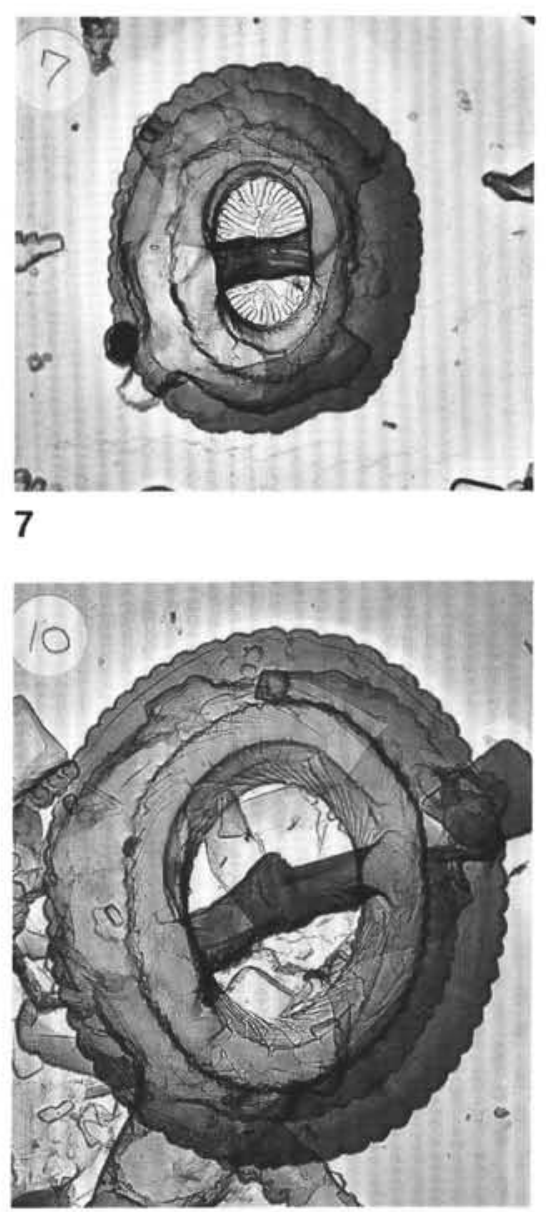

Plate 4. Transmission electron micrographs. All figures have the same magnification. The scale bar in the lower right corner represents $3 \mu \mathrm{m}$. 1-10. Gephyrocapsa sp. D. 1 and 2, Sample 115-709C-1H-4, 112-113 cm (5.62 mbsf); 3 and 4, Sample 115-709C-1H-4, 32-33 cm (4.82 mbsf); 5 and 6, Sample 115-709C-1H-3, 102-103 cm (4.02 mbsf); 7, Sample 115-709C-1H-1, 2-3 cm (0.02 mbsf); 8, Sample 115-709C-1H-2, 52-53 cm (2.02 mbsf); 9 and 10 , Sample $115-709 \mathrm{C}-1 \mathrm{H}-1,42-43 \mathrm{~cm}(0.42 \mathrm{mbsf})$. 